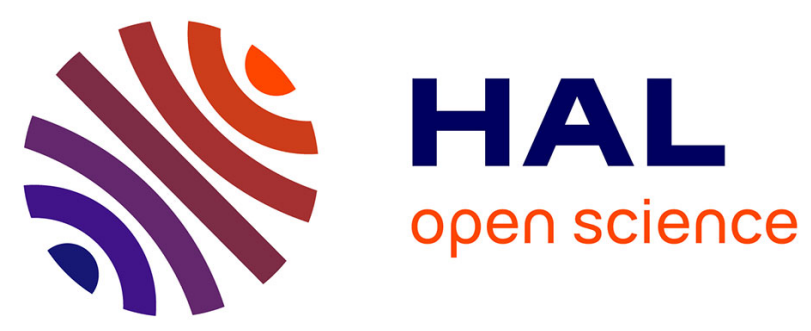

\title{
An assessment of the trophic structure of the Bay of Biscay continental shelf food web: Comparing estimates derived from an ecosystem model and isotopic data
} Géraldine Lassalle, Tiphaine Chouvelon, Paco Bustamante, Nathalie Niquil

\section{- To cite this version:}

Géraldine Lassalle, Tiphaine Chouvelon, Paco Bustamante, Nathalie Niquil. An assessment of the trophic structure of the Bay of Biscay continental shelf food web: Comparing estimates derived from an ecosystem model and isotopic data. Progress in Oceanography, 2014, 120, pp.205-215. 10.1016/j.pocean.2013.09.002 . hal-00922534

\section{HAL Id: hal-00922534 \\ https://hal.science/hal-00922534}

Submitted on 27 Dec 2013

HAL is a multi-disciplinary open access archive for the deposit and dissemination of scientific research documents, whether they are published or not. The documents may come from teaching and research institutions in France or abroad, or from public or private research centers.
L'archive ouverte pluridisciplinaire HAL, est destinée au dépôt et à la diffusion de documents scientifiques de niveau recherche, publiés ou non, émanant des établissements d'enseignement et de recherche français ou étrangers, des laboratoires publics ou privés. 
An assessment of the trophic structure of the Bay of Biscay continental shelf food web: Comparing estimates derived from an ecosystem model and isotopic data G. Lassalle $^{\mathrm{a}, \mathrm{b}, *, \dagger}$, T. Chouvelon ${ }^{\mathrm{a}, \dagger}$, P. Bustamante ${ }^{\mathrm{a}}$, N. Niquil ${ }^{\mathrm{a}, \mathrm{b}}$

${ }^{a}$ Littoral Environnement et Sociétés, UMRi 7266 CNRS-Université de La Rochelle, 2 rue Olympe de Gouges, 17042 La Rochelle, Cedex, France; geraldine.lassalle@ irstea.fr; tiphaine.chouvelon@hotmail.fr; paco.bustamante@univ-lr.fr.

${ }^{\mathrm{b}}$ CNRS, UMR 7208 BOREA, FRE 3484 BIOMEA, Université de Caen Basse Normandie, IBFA, Esplanade de la Paix, CS 14032, 14032 CAEN Cedex 5, France; nathalie.niquil@unicaen.fr.

\footnotetext{
* Corresponding author. IRSTEA, UR EPBX, Estuarine Ecosystems and Migratory Fish, 50 avenue de Verdun, 33612 Cestas cedex, France; Tel.: +33 5578908 02; e-mail addresses: geraldine.lassalle@irstea.fr; geraldinelassalle2@hotmail.com.

${ }^{\dagger}$ Géraldine Lassalle and Tiphaine Chouvelon were co-first authors of this manuscript.
} 
Abstract: Comparing outputs of ecosystem models with estimates derived from experimental and observational approaches is important in creating valuable feedback for model construction, analyses and validation. Stable isotopes and mass-balanced trophic models are well-known and widely used as approximations to describe the structure of food webs, but their consistency has not been properly established as attempts to compare these methods remain scarce. Model construction is a data-consuming step, meaning independent sets for validation are rare. Trophic linkages in the French continental shelf of the Bay of Biscay food webs were recently investigated using both methodologies. Trophic levels for mono-specific compartments representing small pelagic fish and marine mammals and multi-species functional groups corresponding to demersal fish and cephalopods, derived from modelling, were compared with trophic levels calculated from independent carbon and nitrogen isotope ratios. Estimates of the trophic niche width of those species, or groups of species, were compared between these two approaches as well. A significant and close-to-one positive $\left(\mathrm{r}^{2}\right.$ Spearman $\left.=0.72, \mathrm{n}=16, \mathrm{p}<0.0001\right)$ correlation was found between trophic levels estimated by Ecopath modelling and those derived from isotopic signatures. Differences between estimates were particularly low for mono-specific compartments. No clear relationship existed between indices of trophic niche width derived from both methods. Given the wide recognition of trophic levels as a useful concept in ecosystem-based fisheries management, propositions were made to further combine these two approaches.

Keywords: Ecopath model; isotopes; trophic levels; comparative studies; validation; ecosystem management; North-East Atlantic, Bay of Biscay, continental shelf. 


\section{Introduction}

Validation of a model corresponds to a demonstration that, within its domain of applicability, it possesses a satisfactory range of accuracy consistent with the intended application (e.g. Rykiel, 1996). The most classical validation process used with dynamic or predictive models, i.e. simulations, takes the form of a statistical assessment of "goodness-of-fit" between predicted values and the observed data not used in the model development, e.g. ecological niche models with the distribution of a single species (mostly presence/absence data) (Araujo et al., 2005) or, recently, ecosystem classes (Roberts and Hamann, 2012) as the dependent variables. This step does not guarantee that the scientific basis of a model and its internal structure correspond to actual processes or to the cause-effect relationships operating in the real system. However, it can confer a sufficient degree of belief in or credibility to a model to justify its use for research and decision making.

In the growing context of ecosystem-based fisheries management (EBFM) (Garcia et al., 2003; Pikitch et al., 2004), ecosystem models have increasingly been used for forecasting and management purposes (Plagànyi, 2007). They range from extended single-species models incorporating additional inter-specific interactions, e.g. the SeaStar model for the Norwegian herring (Tjelmeland and Lindstrøm, 2005), to complex whole ecosystem models describing all trophic levels (TLs) in the ecosystem, e.g. Ecopath with Ecosim (EwE) (Christensen and Walters, 2004; Christensen et al., 2008) or Linear Inverse Modelling (LIM) (Grami et al., 2011; Legendre and Niquil, 2013) for mass-balanced temporally integrated food web models or Atlantis for spatially explicit bio-geochemical end-to-end ecosystem models (Fulton et al., 2004). Given the potentially high complexity of models used for decision making (Fulton et al., 2003), statistical methods evaluating whether models make reasonable predictions regarding the trophic impacts of fisheries, and of other anthropogenic pressures, on 
ecosystems are still being progressed and are therefore not routinely applied (Christensen and Walters, 2004; Fulton et al., 2011).

Considering the widely used EwE modelling approach (Morissette, 2007), Ecosim dynamic simulations can be validated by assessing their ability to reproduce "reasonably well" the past patterns of change in relative abundance, or catch of major species, by computing a statistical measure of "goodness-of-fit" to these historical data (Pauly et al., 2000; Piroddi et al., 2010). Nevertheless, this critical step requires that independent time series of effort, biomass and catch data for the major species are available at the spatio-temporal scale of interest and incorporating marked trends. Comparing Ecopath model outputs to independent data as a method for evaluating a model's capabilities has increasingly focused on trophic level $(T L)$ estimates (e.g. Kline and Pauly, 1998; Pauly et al., 1998b; Dame and Christian, 2008; Nilsen et al., 2008; Navarro et al., 2011). A radically different approach, stable isotope analysis (SIA), is becoming standard practice for describing trophic interactions in natural systems (Peterson and Fry, 1987; Post, 2002; Bouillon et al., 2011; Miller et al., 2011). Carbon and nitrogen stable isotope ratios, in particular, have been effectively proven to be a valuable source of dietary information when feeding is too difficult to observe. Examples of SIA performed on most representative species of a given ecosystem, from primary producers to top predators, are more and more prevalent in the scientific literature (Davenport and Bax, 2002; Lavoie et al., 2010; Papiol et al., 2012).

The ecosystem assessed in the present work was the well-studied French part of the Bay of Biscay continental shelf. Firstly, the mass-balanced model (Lassalle et al., 2011) was evaluated through comparing TLs calculated using this model with $T L s$ estimated from independent carbon and nitrogen isotope data (Chouvelon et al., 2012a; Chouvelon et al., 2012b). The extent of the validation data for our current study was relatively unique as it incorporated all predators in a large ecosystem, with the exception of seabirds. Predators 
conventionally refer to organisms with $T L s \geq 3.5$. $T L$ can be defined as a dimensionless index defining how much above the primary producer's level (or level 1) an organism feeds on average (Odum and Heald, 1972). Secondly, the cross-comparison realized in this study was further extended to indices of the trophic niche width, providing information about the diversity of resource types consumed by a consumer. For the first time in this type of comparative study, a Bayesian metric based on a standard ellipse was used on isotopic data to estimate the niche breadth (Jackson et al., 2011). This potential method of ecosystem model validation was then discussed in the context of defining indicators of ecosystem health and impacts of fisheries on ecosystems. Finally, propositions were made for a routine that could be added to Ecopath to generalize this validation step.

\section{Material and Methods}

\subsection{Study area}

The Bay of Biscay is a very large bay opening onto the North-East Atlantic Ocean, located from 1 to $10^{\circ} \mathrm{W}$ and from 43 to $48^{\circ} \mathrm{N}$ (Fig. 1). The continental shelf covers over $220000 \mathrm{~km}^{2}$ along the French coast, extending more than $200 \mathrm{~km}$ offshore in the north of the Bay but only $10 \mathrm{~km}$ in the south. Two main river plumes, i.e. the Loire and the Gironde, influence its hydrological structure (Planque et al., 2004; Puillat et al., 2004). The Bay of Biscay also presents a vast oceanic domain and a continental slope indented by numerous canyons (Koutsikopoulos and Le Cann, 1996). These physical and hydrological features greatly influence phytoplankton dynamics and, as a consequence, the whole composition, organisation and functioning of the food web (Varela, 1996). Overall, the Bay of Biscay supports a rich fauna including many protected species, e.g. marine mammals, seabirds, sharks and rays, and is subjected to numerous anthropogenic activities such as important fisheries (Lorance et al., 2009; OSPAR, 2010). 


\subsection{Mass-balanced ecosystem model}

Ecopath with Ecosim is a tool for analysing organic matter and energy flows within a steadystate/static mass-balanced snapshot of the system (Ecopath) and/or a time dynamic simulation module (Ecosim) (Christensen and Walters, 2004; Christensen et al., 2008). Originally proposed by Polovina (1984), the Ecopath model has been combined with routines for network analysis (Ulanowicz, 1986). A detailed description of the main equations of the Ecopath model is described in the first supplementary material (see also www.ecopath.org).

\subsubsection{TLs and omnivory index in Ecopath}

$T L$ was first defined as an integer identifying the trophic position of organisms within food webs (Lindeman, 1942) and was later modified to be fractional (Odum and Heald, 1975). Routinely, a $T L$ was defined as 1 for producers that obtained all of their energy from photosynthesis and detritus that are considered as dead organic matter. For consumers, a $T L$ of $1+[$ the weighted average of the preys' $T L]$ was set. Following this approach, a consumer eating $40 \%$ plants (with $T L=1$ ) and $60 \%$ herbivores (with $T L=2$ ) will have a $T L$ of $1+[0.4$. $1+0.6 \cdot 2]=2.6 . T L$, as a dimensionless index, can be formulated as follows:

$T L_{i}=1+\sum_{j=1}^{n} D C_{i j} \times T L_{j}$

where $i$ is the predator of prey $j, D C_{i j}$ is the fraction of prey $j$ in the diet of predator $i$ and $T L_{j}$ is the trophic level of prey $j$.

The omnivory index $(O I)$ is calculated as the variance of the $T L$ of a consumer's prey groups and is dimensionless (Pauly et al., 1993). A parallel was made with the variance in mathematics calculated by taking the sum of squared differences from the mean and dividing by the number of observations minus one. It measures the variability of $T L s$ on which a group of species feed but does not represent the variability of prey within a $T L$ (i.e. $T L_{j}$ in equation 1 
and 2 already corresponded to average values) nor the variability in feeding behaviour between individual predators. When the $O I$ value is zero, the consumer in question is specialized, i.e. it feeds on a single prey group. A large value indicates that the consumer feeds on prey groups characterized by a large range of $T L s$, and thus shows a more generalist strategy:

$O I_{i}=\sum_{j=1}^{n}\left(T L_{j}-\left(T L_{i}-1\right)\right)^{2} \times D C_{i j}$

where the contribution of each prey $j$ to the variance of the consumer $i$ is a proportion of the fraction of the prey $j$ in the diet of the consumer $i\left(D C_{i j}\right)$. The square root of the $O I$ is the standard deviation (SD) of estimates of TLs (Christensen and Pauly, 1992; Gascuel et al., 2009).

For species that migrate to/from the study area for part of the year, it is possible to take into account their migratory behaviour by setting, in the diet composition matrix, the diet import proportion to the fraction of time spent outside the system. Imports were not considered in the calculation of TLs (Marta Coll, pers. comm.). Ecopath by definition assigns a $T L$ of 1 to detritus. Fishery discards were considered as dead material and were also given a $T L$ of 1 . These assumptions regarding the composition and $T L$ of detrital components should be considered when interpreting $T L$ and $O I$ estimates (Burns, 1989; Nilsen et al., 2008).

\subsubsection{The pre-existing Ecopath model}

A full description of the Bay of Biscay Ecopath implementation can be found in Lassalle et al. (2011); diet compositions were also reproduced in the first supplementary material of the present study. The model considered for this zone was restricted to divisions VIIIa and $\mathrm{b}$ of the International Council for the Exploration of the Sea (ICES; www.ices.dk), and further restricted to the central part of the shelf between the 30-m and 150-m isobaths with a surface area of $102585 \mathrm{~km}^{2}$ (Fig. 1). The model represented a typical year between 1994 and 2005, 
i.e. before the collapse of the European anchovy (Engraulis encrasicolus) and the subsequent five-year closure of the fishery for this species. Thirty-two trophic groups were retained, two of which were seabirds, five marine mammals, nine fish, eight invertebrates, three zooplankton, two primary producers, one bacteria, discards from commercial fisheries and pelagic detritus (Fig. 2). Cephalopods were included in the form of two classes relating to their main oceanic domain (pelagic/benthic). The five main pelagic forage fish were given their own boxes and demersal fish were divided into four multi-species groups on the basis of their diet regime. Marine mammals were included in the form of five mono-specific groups representing the small-toothed cetaceans most frequently encountered in the area.

Based on literature data from similar ecosystems and expert knowledge, the diet regime of seabirds was assumed to be composed mostly of energy-rich pelagic species and large zooplankton crustaceans (Hunt et al., 2005; Certain et al., 2011). It is also well-known that some marine birds feed largely on fishery discards (Arcos, 2001). For cetaceans, diet composition was obtained from stomach content analysis of stranded animals found along the North-East Atlantic French coast (Spitz et al., 2006a; Spitz et al., 2006b; Meynier et al., 2008). Some cetacean species forage both on the shelf and in the oceanic domains of the Bay of Biscay. Consequently, the proportion of oceanic prey in their diet was considered to be imports. For demersal and benthic fish species, knowledge of their diet was obtained from the literature and Fishbase (www.fishbase.org), as well as stomach contents (Le Loc'h, 2004), from carbon and nitrogen stable isotopic analysis performed on specimens captured on a large sedimentary muddy bank known as the "Grande Vasière" and on the external margin of the continental shelf (Le Loc'h et al., 2008). For cephalopods, diet composition was roughly estimated from information gathered for the southern part of the Bay (Cantabrian Sea; Sanchez and Olaso, 2004). Dietary profiles for other invertebrates were determined from SIA on samples from the "Grande Vasière" (Le Loc'h and Hily, 2005; Le Loc'h et al., 2008). 
Stable isotope data integrated during the model construction and those used in the present comparison were obtained from two different scientific campaigns, separated by a few years.

\subsection{Stable isotope data}

\subsubsection{Sampling and sample preparation}

More than 1820 individuals were sampled and analysed for stable isotopes over the Bay of Biscay; these individuals belonged to 142 species covering a wide range of representative taxa of the North-East Atlantic food webs, including marine mammals, both cartilaginous and bony fish, molluscs, crustaceans and plankton. Organisms considered in the present study were those collected from the continental shelf to the shelf-edge of the French part of the Bay of Biscay during the EVHOE Ifremer cruises conducted in the autumns of 2001-2010. Mammal samples came from stranded animals along the French Atlantic coast and were recovered and examined by members of the French Stranding Network between 2000 and 2009. Sample preparation and SIA are fully described in Chouvelon et al. (2012a, b). Briefly, muscle subsamples were freeze-dried, ground into powder and their lipids removed before being analysed using an elemental analyser coupled to a mass spectrometer (Hobson and Welch, 1992; Pinnegar and Polunin, 1999). The results are given in the usual $\delta$ notation relative to the deviation from standards (Pee Dee Belemnite for $\delta^{13} \mathrm{C}$ and atmospheric nitrogen for $\delta^{15} \mathrm{C}$ ) in parts per thousand (\%o). Isotopic results are detailed for all species sampled in the Bay of Biscay in Chouvelon et al. (2012b) and those retained for the present study are presented in the second supplementary material.

\subsubsection{Calculation of species TLs from SIA}

TLs of each organism were estimated according to Post (2002):

$$
T L_{\text {consumer }}=T L_{\text {basis }}+\left(\delta^{15} N_{\text {consumer }}-\delta^{15} N_{\text {basis }}\right) / T E F
$$


where:

- $T L_{\text {basis }}$ is the trophic position of a primary consumer used to estimate the $T L s$ of other consumers in the food web (Vander Zanden and Rasmussen, 1999; Post, 2002), and is assumed to equal 2. In the present study, the great scallop (Pecten maximus), a suspended particulate organic matter (POM) feeder, was identified as the most relevant species for directly reflecting the whole organic matter at the base of food webs, i.e. both pelagic and benthic, in the Bay of Biscay (Chouvelon et al., 2012a). Indeed, the POM is a mixture of primary production, i.e. phytoplankton and/or phytobenthos in coastal areas, and other detrital or regenerated material, therefore representing a compromise when a whole food web, coupling pelagic and benthic organisms, is investigated. In this context, the use of a strictly pelagic or benthic primary consumer as baseline, e.g. a herbivorous pelagic copepod or a benthic grazing snail, would probably lead to under or overestimated isotope-derived TLs in most of high-trophic level consumers, because these latter probably depend on both pelagic and benthic production, or even partly on regenerated material.

- $\delta^{15} N_{\text {consumer }}$ is the value measured for the consumer.

- $\delta^{15} N_{\text {basis }}$ corresponds to the value of the primary consumer $P$. maximus. However, in the Bay of Biscay area, a strong and consistent inshore-offshore gradient of isotopic signatures (both $\delta^{13} \mathrm{C}$ and $\delta^{15} \mathrm{~N}$ ) exists and was evidenced in the filter-feeding bivalve $P$. maximus in particular, but in other trophic guilds as well (Chouvelon et al., 2012a; Nerot et al., 2012). As such, Chouvelon et al. (2012a) proposed a correction for $\delta^{15} N_{\text {basis. }}$ This correction is based on the regression parameters obtained for individuals of $P$. maximus sampled along the inshoreoffshore gradient and accounts for the $\delta^{13} \mathrm{C}$ value of the consumer considered, which results in (see details in Chouvelon et al. 2012a):

$\delta^{15} N_{\text {basis }}=1.556 \cdot \delta^{13} C_{\text {consumer }}+33.47$ 
- TEF is the trophic enrichment factor for the $\delta^{15} \mathrm{~N}$ difference between a source and its consumer. A TEF appropriate to each major type of consumer analysed in this study was derived from the literature. Values were summarized in the third supplementary material calculated from Chouvelon et al., 2012a.

The final equation used for $T L s$ ' calculation was thus:

$T L_{\text {consumer }}=T L_{\text {basis }}+\left[\delta^{15} N_{\text {consumer }}-\left(1.556 \cdot \delta^{13} C_{\text {consumer }}+33.47\right)\right] / T E F$

Finally, values of stable-isotope-derived $T L s$ are presented for all species analysed in the Bay of Biscay in Chouvelon et al. (2012a) and for those useful in the present study in Table 1.

\subsubsection{Calculation of trophic niche width from SIA}

The niche width of each species or group of species was described in terms of the area the population occupies on a $\delta^{13} \mathrm{C}-\delta^{15} \mathrm{~N}$ biplot based on all individuals within a species (Table 1). The area was determined by a sample size-corrected version of the Bayesian estimate of the standard ellipse area $\left(S E A_{c}\right.$; similar to $S D$ but for bivariate data), as described in Jackson et al. (2011). All analyses were performed with $\mathrm{R}$ ( $\mathrm{R}$ foundation core team, 2011) using the package SIAR (Stable Isotope Analysis in R; version 4.1.3), including SIBER metrics (Stable Isotope Bayesian Ellipses in R) (Parnell et al., 2010), and required only individual raw data. See Layman et al. $(2007,2012)$ for original descriptions of the community-level metrics and current analytical tools available for examining food web structure using stable isotopes.

\subsection{Comparison between Ecopath and isotope results}

The trophic level estimated by the Ecopath model $\left(T L_{E c o p a t h}\right)$ was plotted against the corresponding trophic level estimated by SIA $\left(T L_{S I A}\right)$ and their correlation was tested using the Spearman-rank correlation coefficient test. For multi-species model compartments, $T L_{S I A}$ was determined as the mean $T L$ of the species included in the model compartment 
composition for which SIA data existed, weighted by their biomass proportions. Similarly, correlations were analysed between the square root of $O I$ estimated from the Ecopath model and the $S D$ of stable-isotope-derived $T L$ and, finally, between $S E A_{c}$ and $O I$ values. All the indicators used in the present study are unitless (Table 1).

\section{Results}

\subsection{Ecopath outputs}

Firstly, none of the compartments retained in the comparative study was found to feed on discards or detritus in significant proportions (Fig. 2). Both striped dolphins (Stenella coeruleoalba) and long-finned pilot whales (Globicephala melas) derived a substantial part of their diet from imports of the oceanic domain.

TLs estimated using the Ecopath model ranged from 3.41 (benthivorous demersal fish) to 5.09 (bottlenose dolphins (Tursiops truncatus)). The OI estimated using the same approach indicated that species, or groups of species, ranged from highly specialized consumers $(O I=0$ for anchovy and sprat (Sprattus sprattus)) to generalist predators, with long-finned pilot whales having an $O I$ value of 1.91 .

\subsection{SIA outputs}

Trophic levels derived from isotopic data varied between 3.42 (benthic cephalopods) and 5.33 (bottlenose dolphins). Based on this approach, three species of marine mammals had a $T L$ above 5. When calculating the ratio of $S D$ to the mean isotope-derived $T L$ for each compartment, also known as the coefficient of variation $(\mathrm{CV})$, values ranged between $2.58 \%$ for ichtyophageous demersal fish to $11.63 \%$ for bottlenose dolphins. The estimators of trophic niche width, $S D$ and $S E A_{c}$, yielded two distinct classifications of functional groups in terms of 
omnivory and generalism. However, in both cases, bottlenose dolphins and long-finned pilot whales presented the largest spectrum of prey consumption (Fig. 3).

\subsection{Comparison between Ecopath and isotope results}

Of the 121 species of marine mammals, fish and cephalopods analysed using stable isotopes, 64 corresponded to those included in the Ecopath model of the French Bay of Biscay continental shelf food web, and were distributed in 16 distinct mono- or multi-species compartments. This corresponded to 67\% (1150 of 1706 individuals) of all marine mammal, fish and cephalopod individuals analysed using stable isotopes in the whole Bay of Biscay ecosystem. When the biomass contributions of species for which stable isotope data were available were summed within each multi-species biological compartment, between 64 to $100 \%$ of the total compartment biomass was represented (Table 1), confirming that the dominant species had been analysed using stable isotopes. Regarding the number of species within a compartment benefiting from SIA, the percentage of representativeness varied between $25 \%$ for piscivorous demersal fish, i.e. one species analysed out of the four forming the model box, to as high as $100 \%$ for benthic and pelagic cephalopods, respectively. The most abundant species in terms of biomass in all multi-species compartments was also that containing the highest number of individuals analysed by stable isotopes. Benthos compartments were defined on the basis of the main feeding behaviour and the position of organisms in relation to the sea bottom. The composition of each box was not established to the species level, but rather to the major taxonomic groups. Isotope data for crustaceans and invertebrates were therefore not used in the present comparison.

TLs estimated by the Ecopath model were highly and positively correlated with those derived from SIA $\left(\mathrm{r}^{2}\right.$ Spearman $\left.=0.72, \mathrm{n}=16, \mathrm{p}<0.0001\right)($ Fig. $4 \mathrm{a})$. Most points were above the 1:1 line of perfect agreement in the range of TLs being studied, suggesting that Ecopath analysis 
tended to slightly underestimate trophic positions (Fig. 4a). Perfect agreement was found for two compartments, a mono-species compartment corresponding to striped dolphins (3), and the most diverse multi-species compartment regrouping piscivorous and benthivorous demersal fish (9). The difference between the TLs estimated by both methods relative to the Ecopath-derived values did not exceed $13 \%$. No relationship was found between the degree of agreement, defined here as the difference between the TLs estimated by both methods, and the percentage of representativeness of species analysed for isotopes relative to species forming the Ecopath boxes. Regarding indices of trophic niche width, no clear relationship appeared between these methods, i.e. no significant correlations (Fig. 4b, c). Only some species or groups of species showed a good correspondence. Among the most remarkable findings, the long-finned pilot whale was demonstrated by both methods to have the largest trophic niche. The $O I$ value for this species was suspected to be uncertain as half of its feeding activity was described to take place outside the study area (proportion of imports of 0.559 in the Ecopath model). However, stable isotopes (high $S E A_{c}$ value) also suggested some degree of dietary plasticity for this marine mammal (Fig. 4c). The bottlenose dolphin also pertained to the upper half of the figures (Fig. 4b, c), corresponding to high values of trophic niche width derived from stable isotopes. As such, dietary profiles of dolphin individuals determined from stable isotopes were multiple. However, this species was characterized by an intermediate $O I$ value, indicating the consumption of a rather moderate diversity of prey TLs.

\section{Discussion}

\subsection{A comparison of trophic indices in the light of methodological choices and assumptions}

Stable isotope data are consistent with $T L s$ estimated from the model as an initial independent test of model validity. A correlation of 0.7 is generally considered to be a threshold value 
(Green, 1979) and the associated test $(\mathrm{p}<0.0001)$ concluded there was a strongly significant relationship. The slight deviation from the 1:1 line of perfect agreement could to some extent be related to data time periods. Data used for model building covered the period 1994-2005, whereas stable isotope data were gathered from individuals mostly collected between 2006 and 2010. Nevertheless, both sets of data encompassed the same geographic area in the Bay of Biscay. The time interval was marked by the closure of the European anchovy fishery from June 2006 to December 2009 (ICES, 2012a) and agreement to the recovery plan for northern hake (Merluccius merluccius) stock in 2004 (ICES, 2012b).

There are other potential factors associated with both methods that could be advanced to explain this deviation. In Ecopath, the convention of using detritus and discarded material as $T L 1$ has probably resulted in lower model $T L$ estimates relative to those calculated from SIA (Nilsen et al., 2008; Navarro et al., 2011). Here, compartments retained in the comparison only fed a little on this resource, so the potential effects of model assumptions regarding detritus would be mostly indirect and mitigated, propagating from lower TLs to secondary consumers and top predators. No systematic bias was found among comparative studies, i.e. two studies highlighted a potential underestimation of Ecopath-based $T L$ estimates (the present work and the one of Milessi et al. (2010)), one came to the opposite conclusion (Polunin and Pinnegar, 2000), and another found a direction varying across TLs (Nilsen et al., 2008). Secondly, setting imports implicates that part of the feeding activity was performed outside the study area and that diet regime proportions were potentially more uncertain. However, diet regimes for the two marine mammals species for which imports were relevant in the present study (the long-finned pilot whale and the striped dolphin) were well-known across the whole Bay of Biscay (Spitz et al., 2006a; Spitz et al., 2011) and thus $T L$ estimates agreed particularly well between the two methods. Finally, groups considered as important but about which little is known can be included in Ecopath models. This was the case here for 
cephalopod diets based on data from a neighbouring area, i.e. the Cantabrian Sea (Sanchez and Olaso, 2004). As a result, the largest discrepancy between $T L$ estimates was noticed for pelagic cephalopods, i.e. the point was far from the 1:1 line of agreement in Figure 4a.

In SIA, trophic enrichment factors (TEF) appropriate to each of the four major types of consumers analysed in the present study were used (Chouvelon et al., 2012a). However, TEF values which were not specific to the Bay of Biscay should be acknowledged as a potential source of uncertainty in $T L$ results. The selection of herbivorous organisms for setting reference values for $\delta^{15} \mathrm{~N}$ at the base of the food web remained nonetheless the main critical assumption. The great scallop, retained as the most relevant primary consumer on the French continental shelf of the Bay of Biscay (Chouvelon et al., 2012a; Nerot et al., 2012), exhibits an aggregated distribution with many relatively small fishing grounds that are quite widely separated (Mahé et al., 2006). This discontinuous spatial coverage could potentially lead to discrepancies in the $T L$ comparison. A new method based on the $\delta^{15} \mathrm{~N}$ values of two amino acids from a single organism potentially yielded a smaller error in estimating trophic level, compared to the conventional isotope method (Chikaraishi et al., 2009), and still remains to be compared to model outputs.

The absence of a relationship between indices of trophic niche width was also noted in the study of Navarro et al. (2011). This was very probably explained by the divergence in the meaning given to omnivory in ecosystem models and SIA. OI was defined and implemented as the variance of $T L s$ in a consumer's diet (Christensen et al., 2008). A population that appears to show a large dietary niche width is either composed of generalist individuals all consuming a wide range of food types and therefore all having the same omnivorous diet (Type A generalization/individual generalism), or of individuals each specializing on a different but narrow range of food types (Type B generalization/population generalism) (Van Valen, 1965; Grant et al., 1976). It is not possible to discriminate between the two alternatives 
using $O I$ and the diet input matrix as entered in Ecopath. In both the cases of generalism described above, OI values would be high. Performing SIA on tissues which integrate variations over relatively long timescales, such as muscles, and obtaining a high $S E A_{c}$ value or $S D$ around the mean $T L$ using these isotope data collected at the individual scale, would only discriminate Type B generalists (Bearhop et al., 2004). At the opposite end of the spectrum, a population composed of "individual" specialists (all individuals feeding on the same narrow range of food types) could be identified by possessing a low OI. With SIA, both specialists and Type A generalists would be characterized by a small trophic niche width. In fact, using SIA, one must keep in mind that only differences are really informative on a consumer's strategy. A high SEAc measure for a species effectively clearly indicates that the prey composition of the individuals analysed, i.e. both prey items and the quantity of each prey item ingested, was different. On the contrary, a low SEAc measure for a species is less informative, because it results from one of the three following different strategies: 1) the prey composition of the individuals analysed was identical, giving them similar signatures; 2) their prey composition was different but the different prey items did not present distinct signatures, leading to similar signatures in consumer's individuals; 3 ) the prey items were the same and presented distinct signatures, but the quantity of each item ingested was different between consumer's individuals, leading to similar signatures consumer's individuals, i.e. mixture of distinct signatures. Additionally, multi-species compartments were used in the present study, probably mixing dietary generalists with specialists within a functional group, and consequently further preventing any potential relationship being found between trophic niche width indices. 


\subsection{Management benefits of reduced uncertainty of $T L$ estimates}

In the context of the Marine Strategy Framework Directive (MSFD; 2008/56/EC), indicators including mean community and catch $T L s$ and biomass per $T L$ can be used to study ecosystem responses to overfishing; for a recent synthesis on ecosystem health indicators, see Rombouts et al. (2013a, b). Biomass can be considered simultaneously over several TLs and can therefore become an ecosystem-based indicator. For example, fishing selectively removes large fish from the oceans, thereby reducing the mean $T L$ of catches and creating a phenomenon known as "fishing down the food web" (Pauly et al., 1998a). The marine trophic index (MTI) measures the change in mean $T L$ of fishery landings on an annual basis from a combination of fishery landings and dietary composition data (Pauly and Watson, 2005). The $T L$ of the landings was retained as an indicator in the first phase of the IndiSeas project for evaluating, comparing and communicating the ecological status of exploited marine ecosystems (www.indiseas.org/; Shin et al., 2010). Biomass trophic spectra, defined as the continuous biomass distribution by trophic class (from herbivores and detritivores to top predators), have been used to assess trophic structure and functioning in relation to fishing pressure (Gascuel and Pauly, 2009; Gasche et al., 2012; Lassalle et al., 2012). In addition, of the different alternatives for building trophic spectra, Libralato and Solidoro (2010) concluded that using the $O I$ index, even if roughly estimated, was relevant as a measure of the dispersion of the prey of a given predator. Consequently, the wide utilization of TLs as ecosystem health indicators turns comparisons between outputs from ecosystem modelling and isotope-derived estimates into a necessary step in the assessment of the state of ecosystems, by providing a better perspective on the issue of uncertainty. This is even truer when considering the fact that isotopes integrate better the information over time and over TLs. 


\subsection{Towards further combination of these two complementary approaches}

Among the seven studies examining the relation between $T L s$ estimated by these two independent methods (Table 2), only four can be retained for an intersite comparison. All $\mathrm{r}^{2}$ values were superior to 0.70 indicating a high agreement between methods. This further underlined the importance of using both methods conjointly for a given ecosystem.

As a first step, Dame and Christian (2008) proposed modifying models when validation is not made until agreement between trophic level estimates is reached, and then comparing various outputs from ecological network analysis (ENA) between the unmodified and modified models in order to assess their sensitivity to the structure of the model. In the present study, we proposed one element in model construction to which modellers should pay particular attention. The low trophic levels (LTL) in the Bay of Biscay model were particularly complex, with the zooplankton community being divided by size classes. Their feeding habits integrate cannibalism, intra-guild predation, microbial loop processes and the general consumption of phytoplankton. Consequently, their $T L$ values ranged between 2.177 and 2.672. TLs of the whole food web were recalculated considering the simplest basal structure without bacteria and with only one class of herbivorous zooplankton. Considering zooplankton as strict primary consumers with a $T L$ of 2 has led to a systematic decrease of food web $T L$ values and further to a lower correlation coefficient between Ecopath-based and SIA estimates $\left(\mathrm{r}^{2}\right.$ Spearman $=0.55, \mathrm{n}=16$, not significant at the 0.0001 level $)$. This comparison of two alternative model structures highlighted the need for a realistic representation of LTL into models to increase the reliability of their outputs.

Beyond comparative studies of the outputs derived from both methods (Milessi et al., 2010; Navarro et al., 2011) and the use of isotope data to define model diet composition matrices (e.g. Baeta et al., 2011), full integration of the isotope data into the modelling process was first tested in conventional Linear Inverse Modelling (LIM). When biologically realistic 
boundaries to the unmeasured flows between biological compartments were defined/constrained using $\delta^{13} \mathrm{C}$ stable isotope data in a LIM model, the uncertainty in the food web reconstruction was reduced significantly (Eldridge et al., 2005; Van Oevelen et al., 2006). The range of values that a flow can attain with a given data set decreased by $>50 \%$ for $60 \%$ of the flows. In addition to this, a simple methodology to incorporate information from multiple stable isotope elements, i.e. ${ }^{13} \mathrm{C},{ }^{15} \mathrm{~N}$, etc., into food web models using the new and complex Linear Inverse Model Markov Chain Monte Carlo (LIM-MCMC) technique, has recently been proposed and also demonstrated capability to reduce uncertainty in food web model solutions (Pacella et al., Submitted). Furthermore, from the stable isotope information concerning all consumers and resources in a food web, IsoWeb, a novel Bayesian mixing model using MCMC methods, can estimate the dietary proportions of all consumers (Kadoya et al., 2012). This is a crucial step in quantifying the strength of the interactions for a whole food web and for further analysing the dynamics and stability of this food web using ecosystem models such as EwE. However, isotopic signatures of the different primary producers available to food web primary consumers are required to run IsoWeb. In the specific case of the Bay of Biscay, these basal signatures have not yet been determined.

Despite the interest raised by a number of researchers on these issues (Milessi et al., 2010; Navarro et al., 2011), no definite approach to the calculations of $T L$ using isotope data in Ecopath has to date been developed (Villy Christensen, pers. comm.). As a first initial step, comparison of $T L$ estimates could be automated by the inclusion of an input table in which individual isotope values could be entered by model compartment, when available. Then, in the Ecopath parameterization section, a routine to calculate isotope-derived TLs and to assess the correlation with Ecopath estimates could be developed. As part of the deviation between estimates can be imputed to the quality of diet data, this routine could help to quantify the uncertainty related to the model input values and would as such complement the diagnosis of 
the pedigree index already in use in Ecopath (Christensen et al., 2008). In addition, large differences between paired values ( $T L$ derived from both methods) would also guide modellers and researchers involved in the collection of data in the field in order to refine the diet regime for these specific compartments. But, it should be kept in mind that some discrepancies could be linked to indicators in it selves as they do not encompass all forms of trophic variability.

\section{Acknowledgements}

This research has been mainly supported by EU FP7 grant FACTS (Forage Fish Interactions; www.facts-project.eu), grant agreement no. 244966 and by the large collaborative European project REPRODUCE (EraNet-MariFish, ERAC-CT-2006-025989). It was also supported, in a lesser extent, by the project DEVOTES (DEVelopment Of innovative Tools for understanding marine biodiversity and assessing good Environmental Status) funded by the European Union under the 7th Framework Programme, 'The Ocean for Tomorrow' Theme (grant agreement no. 308392; www.devotes-project.eu). Authors are grateful to IFREMER staff for sampling during EVHOE cruises and members of the French Stranding Network for marine mammals' samples collection, G. Guillou and P. Richard (LIENSs) for assistance in isotopic analysis, and all contributors to the Ecopath model (see Lassalle et al., 2011). Many thanks go to B. Simon-Bouhet (LIENSs) for his help on standard ellipse graphical representation. 


\section{References}

Araujo, M.B., Pearson, R.G., Thuiller, W., Erhard, M., 2005. Validation of species-climate impact models under climate change. Global Change Biology 11, 1504-1513.

Arcos, J.M., 2001. Foraging ecology of seabirds at sea: significance of commercial fisheries in the NW Mediterranean. PhD Thesis, University of Biology, Animal Biology Department, Barcelona, Spain.

Baeta, A., Niquil, N., Marques, J.C., Patrício, J., 2011. Modelling the effects of eutrophication, mitigation measures and an extreme flood event on estuarine benthic food webs. Ecological Modelling 222, 1209-1221.

Bearhop, S., Adams, C.E., Waldron, S., Fuller, R.A., Macleod, H., 2004. Determining trophic niche width: a novel approach using stable isotope analysis. Journal of Animal Ecology 73, 1007-1012.

Bouillon, S., Connolly, R.M., Gillikin, D.P., 2011. Use of stable isotopes to understand food webs and ecosystem functioning in estuaries. In: Wolanski, E., McLusky, D. (Eds.), Treatise on Estuarine and Coastal Science. Academic Press, Waltham, pp. 143-173.

Burns, T.P., 1989. Lindeman's contradiction and the trophic structure of ecosystems. Ecology $70,1355-1362$.

Certain, G., Masse, J., Van Canneyt, O., Petitgas, P., Doremus, G., Santos, M., Ridoux, V., 2011. Investigating the coupling between small pelagic fish and marine top predators using data collected from ecosystem-based surveys. Marine Ecology Progress Series 422, 23-39.

Chikaraishi, Y., Ogawa, N.O., Kashiyama, Y., Takano, Y., Suga, H., Tomitani, A., Miyashita, H., Ohkouchi, N., 2009. Determination of aquatic food-web structure based on compoundspecific nitrogen isotopic composition of amino acids. Limnology and Oceanography: Methods 7, 740-750. 
Chouvelon, T., Spitz, J., Caurant, F., Mèndez-Fernandez, P., Autier, J., Lassus-Débat, A., Chappuis, A., Bustamante, P., 2012a. Enhanced bioaccumulation of mercury in deep-sea fauna from the Bay of Biscay (north-east Atlantic) in relation to trophic positions identified by analysis of carbon and nitrogen stable isotopes. Deep Sea Research Part I: Oceanographic Research Papers 65, 113-124.

Chouvelon, T., Spitz, J., Caurant, F., Mèndez-Fernandez, P., Chappuis, A., Laugier, F., Le Goff, E., Bustamante, P., 2012b. Revisiting the use of $\delta^{15} \mathrm{~N}$ in meso-scale studies of marine food webs by considering spatio-temporal variations in stable isotopic signatures - The case of an open ecosystem: the Bay of Biscay (North-East Atlantic). Progress In Oceanography $101,92-105$.

Christensen, V., Pauly, D., 1992. ECOPATH II - a software for balancing steady-state ecosystem models and calculating network characteristics. Ecological Modelling 61, 169-185. Christensen, V., Walters, C.J., 2004. Ecopath with Ecosim: methods, capabilities and limitations. Ecological Modelling 172, 109-139.

Christensen, V., Walters, C.J., Pauly, D., Forrest, R., 2008. Ecopath with Ecosim version 6. User guide - November 2008. Lenfest Ocean Futures Project 2008. Fisheries Centre, The University of British Columbia, Vancouver, Canada.

Dame, J.K., Christian, R.R., 2008. Evaluation of ecological network analysis: validation of output. Ecological Modelling 210, 327-398.

Davenport, S.R., Bax, N.J., 2002. A trophic study of a marine ecosystem off southeastern Australia using stable isotopes of carbon and nitrogen. Canadian Journal of Fisheries and Aquatic Sciences 59, 514-530.

Eldridge, P.M., Cifuentes, L.A., Kaldy, J.E., 2005. Development of a stable-isotope constraint system for estuarine food-web models. Marine Ecology Progress Series 303, 73-90. 
Fulton, A.E., Fuller, M., Smith, A.D.M., Punt, A.E., 2004. Ecological indicators of the ecosystem effects of fishing: final report. Australian Fisheries Management Authority Report, R99/1546.

Fulton, E.A., Link, J.S., Kaplan, I.C., Savina-Rolland, M., Johnson, P., Ainsworth, C., Horne, P., Gorton, R., Gamble, R.J., Smith, A.D.M., Smith, D.C., 2011. Lessons in modelling and management of marine ecosystems: the Atlantis experience. Fish and Fisheries 12, 171-188.

Fulton, E.A., Smith, A.D.M., Johnson, C.R., 2003. Effect of complexity on marine ecosystem models. Marine Ecology Progress Series 253, 1-16.

Garcia, S.M., Zerbi, A., Aliaume, C., Do Chi, T., Lasserre, G., 2003. The ecosystem approach to fisheries - Issues, terminology, principles, institutional foundations, implementation and outlook. FAO Fisheries Technical Paper, Vol. 443. FAO, Rome, Italy.

Gasche, L., Gascuel, D., Shannon, L., Shin, Y.J., 2012. Global assessment of the fishing impacts on the Southern Benguela ecosystem using an EcoTroph modelling approach. Journal of Marine Systems 90, 1-12.

Gascuel, D., Pauly, D., 2009. EcoTroph: modelling marine ecosystem functioning and impact of fishing. Ecological Modelling 220, 2885-2898.

Gascuel, D., Tremblay-Boyer, L., Pauly, D., 2009. EcoTroph (ET): a trophic level based software for assessing the impacts of fishing on aquatic ecosystems. Fisheries Centre Research Reports, Vol. 17(1). Fisheries Centre, University of Bristish Columbia, Vancouver, Canada.

Grami, B., Rasconi, S., Niquil, N., Jobard, M., Saint-Béat, B., Sime-Ngando, T., 2011. Functional effects of parasites on food web properties during the spring diatom bloom in Lake Pavin: A linear inverse modeling analysis. PLoS ONE 6, e23273. 
Grant, P.R., Grant, B.R., Smith, J.N., Abbott, I.J., Abbott, L.K., 1976. Darwin's finches: population variation and natural selection. Proceedings of the National Academy of Sciences $73,257-261$.

Green, R.H., 1979. Sampling design and statistical methods for environmental biologists. Wiley.

Hobson, K.A., Welch, H.E., 1992. Determination of trophic relationships within a high Arctic marine food web using $\delta^{13} \mathrm{C}$ and $\delta^{15} \mathrm{C}$ analysis. Marine Ecology Progress Series 84, 9-18.

Hunt, G.L., Drew, G.S., Jahncke, J., Piatt, J.F., 2005. Prey consumption and energy transfer by marine birds in the Gulf of Alaska. Deep Sea Research Part II: Tropical Studies in Oceanography 52, 781-797.

ICES, 2012a. Report of the working group on anchovy and sardine (WGANSA). ICES CM 2012/ACOM:16.

ICES, 2012b. Report of the working group on the assessment of Southern shelf stocks of hake, monk and megrim (WGHMM). ICES CM 2012/ACOM:11.

Jackson, A.L., Inger, R., Parnell, A.C., Bearhop, S., 2011. Comparing isotopic niche widths among and within communities: SIBER - Stable Isotope Bayesian Ellipses in R. Journal of Animal Ecology 80, 595-602.

Kadoya, T., Osada, Y., Takimoto, G., 2012. IsoWeb: a Bayesian isotope mixing model for diet analysis of the whole food web. PLoS ONE 7, e41057.

Kline, T., Pauly, D., 1998. Cross-validation of trophic level estimates from a mass balance model of Prince William Sound using 15N/14N data. In: Funk, F., Quinn II, T.J., Heifetz, J., Ianelli, J.N., Powers, J.E., Schweigert, J.F., Sullivan, P.J., Zhang, C.-I. (Eds.), Fishery Stock Assessment Models. Alaska Sea Grant College Program Report No AK-SG-98-01, University of Alaska, Fairbanks, USA, pp. 693-702. 
Koutsikopoulos, C., Le Cann, B., 1996. Physical processes and hydrological structures related to the Bay of Biscay anchovy. Scientia Marina 60, 9-19.

Lassalle, G., Gascuel, D., Le Loc'h, F., Lobry, J., Pierce, G.J., Ridoux, V., Santos, M.B., Spitz, J., Niquil, N., 2012. An ecosystem approach for the assessment of fisheries impacts on marine top-predators: the Bay of Biscay case study. ICES Journal of Marine Science 69, 925938.

Lassalle, G., Lobry, J., Le Loc'h, F., Bustamante, P., Certain, G., Delmas, D., Dupuy, C., Hily, C., Labry, C., Le Pape, O., Marquis, E., Petitgas, P., Pusineri, C., Ridoux, V., Spitz, J., Niquil, N., 2011. Lower trophic levels and detrital biomass control the Bay of Biscay continental shelf food web: implications for ecosystem management. Progress In Oceanography 91, 61-75.

Lavoie, R.A., Hebert, C.E., Rail, J.F., Braune, B.M., Yumvihoze, E., Hill, L.G., Lean, D.R.S., 2010. Trophic structure and mercury distribution in a Gulf of St. Lawrence (Canada) food web using stable isotope analysis. Science of The Total Environment 408, 5529-5539.

Layman, C.A., Araujo, M.S., Boucek, R., Hammerschlag-Peyer, C.M., Harrison, E., Jud, Z.R., Matich, P., Rosenblatt, A.E., Vaudo, J.J., Yeager, L.A., Post, D.M., Bearhop, S., 2012. Applying stable isotopes to examine food-web structure: an overview of analytical tools. Biological Reviews 87, 545-562.

Layman, C.A., Arrington, D.A., Montana, C.G., Post, D.M., 2007. Can stable isotope ratios provide for community-wide measures of trophic structure? Ecology 88, 42-48.

Le Loc'h, F., 2004. Structure, fonctionnement, évolution des communautés benthiques des fonds meubles exploités du plateau continental Nord-Gascogne. Thèse de Doctorat, Université de Bretagne Occidentale, Océanographie Biologique, Brest, France. 
Le Loc'h, F., Hily, C., 2005. Stable carbon and nitrogen isotope analysis of Nephrops norvegicus / Merluccius merluccius fishing grounds in the Bay of Biscay (Northeast Atlantic). Canadian Journal of Fisheries and Aquatic Sciences 62, 123-132.

Le Loc'h, F., Hily, C., Grall, J., 2008. Benthic community and food web structure on the continental shelf of the Bay of Biscay (North Eastern Atlantic) revealed by stable isotopes analysis. Journal of Marine Systems 72, 17-34.

Legendre, L., Niquil, N., 2013. Large-scale regional comparisons of ecosystem processes: Methods and approaches. Journal of Marine Systems 109-110, 4-21.

Libralato, S., Solidoro, C., 2010. Comparing methods for building trophic spectra of ecological data. ICES Journal of Marine Science 67, 426-434.

Lindeman, R., 1942. The trophic-dynamic aspect of the ecology. Ecology 23, 399-418.

Lorance, P., Bertrand, J.A., Brind'Amour, A., Rochet, M.J., Trenkel, V.M., 2009. Assessment of impacts from human activities on ecosystem components in the Bay of Biscay in the early 1990s. Aquatic Living Resources 22, 409-431.

Mahé, K., Delpech, J.P., Carpentier, A., 2006. Synthèse bibliographique des principales espèces de Manche orientale et du golfe de Gascogne. Ifremer, Boulogne-sur-Mer, France.

Meynier, L., Pusineri, C., Spitz, J., Santos, M.B., Pierce, G.J., Ridoux, V., 2008. Intraspecific dietary variation in the short-beaked common dolphin (Delphinus delphis) in the Bay of Biscay: importance of fat fish. Marine Ecology Progress Series 354, 277-287.

Milessi, A.C., Calliari, D., Rodríguez-Grana, L., Conde, D., Sellanes, J., Rodríguez-Gallego, L., 2010. Trophic mass-balance model of a subtropical coastal lagoon, including a comparison with a stable isotope analysis of the food-web. Ecological Modelling 221, 2859-2869.

Miller, T.W., Van der Lingen, C.D., Brodeur, R., Omori, K., Hamaoka, H., Isobe, T., 2011. Understanding what drives food web structure in marine pelagic ecosystems. In: Omori, K., Guo, X., Yoshie, N., Fujii, N., Handoh, I.C., Isobe, A., Tanabe, S. (Eds.), Interdisciplinary 
studies on environmental chemistry - marine environmental modeling and analysis, pp. 125131.

Morissette, L., 2007. Complexity, cost and quality of ecosystem models and their impact on ecosystem resilience: a comparative analysis, with emphasis on marine mammals and the Gulf of St Lawrence. PhD Thesis, University of British Columbia, Zoology.

Navarro, J., Coll, M., Louzao, M., Palomera, I., Delgado, A., Forero, M.G., 2011. Comparison of ecosystem modelling and isotopic approach as ecological tools to investigate food webs in the NW Mediterranean Sea. Journal of Experimental Marine Biology and Ecology 401, 97-104.

Nerot, C., Lorrain, A., Grall, J., Gillikin, D.P., Munaron, J.M., Le Bris, H., Paulet, Y.M., 2012. Stable isotope variations in benthic filter feeders across a large depth gradient on the continental shelf. Estuarine, Coastal and Shelf Science 96, 228-235.

Nilsen, M., Pedersen, T., Nilssen, E.M., Fredriksen, S., 2008. Trophic studies in a highlatitude fjord ecosystem: a comparison of stable isotope analyses $\left(\delta^{13} \mathrm{C}\right.$ and $\left.\delta^{15} \mathrm{~N}\right)$ and trophiclevel estimates from a mass-balance model. Canadian Journal of Fisheries and Aquatic Sciences 65, 2791-2806.

Odum, W.E., Heald, E.J., 1972. Trophic analyses of an estuarine mangrove community. Bulletin of Marine Science 22, 671-738.

Odum, W.E., Heald, E.J., 1975. The detritus-based food web of an estuarine mangrove community. In: Cronin, L.E. (Ed.), Estuarine Research. Academic Press, New-York, USA, pp. 265-286.

OSPAR, 2010. Quality Status Report 2010. OSPAR (Oslo-Paris) Commission, London, U.K. Pacella, S., Lebreton, B., Richard, P., Phillips, D., Dewitt, T., Niquil, N., Submitted. Incorporation of diet information derived from Bayesian stable isotope mixing models into 
mass-balanced marine ecosystem models: A case study from the Marennes-Oléron Estuary, France. Ecological Modelling.

Papiol, V., Cartes, J.E., Fanelli, E., Rumolo, P., 2012. Food web structure and seasonality of slope megafauna in the NW Mediterranean elucidated by stable isotopes: relationship with available food sources. Journal of Sea Research 77, 53-69.

Parnell, A.C., Inger, R., Bearhop, S., Jackson, A.L., 2010. Source partitioning using stable isotopes: coping with too much variation. PLoS ONE 5, e9672.

Pauly, D., Christensen, V., Dalsgaard, J., Froese, R., Torres, F., 1998a. Fishing down marine food webs. Science $279,860-863$.

Pauly, D., Christensen, V., Walters, C., 2000. Ecopath, Ecosim, and Ecospace as tools for evaluating ecosystem impact of fisheries. ICES Journal of Marine Science 57, 697-706.

Pauly, D., Soriano-Bartz, M.L., Palomares, M.L.D., 1993. Improved construction, parametrization and interpretation of steady-state ecosystem models. In: Christensen, V., Pauly, D. (Eds.), Trophic models of aquatic ecosystems, pp. 1-13.

Pauly, D., Trites, A.W., Capuli, E., Christensen, V., 1998b. Diet composition and trophic levels of marine mammals. ICES Journal of Marine Science 55, 467-481.

Pauly, D., Watson, R., 2005. Background and interpretation of the 'Marine Trophic Index' as a measure of biodiversity. Philosophical Transactions of the Royal Society B: Biological Sciences 360, 415-423.

Peterson, B.J., Fry, B., 1987. Stable isotopes in ecosystem studies. Annual Review of Ecology and Systematics 18, 293-320.

Pikitch, E.K., Santora, C., Babcock, E.A., Bakun, A., Bonfil, R., Conover, D.O., Dayton, P., Doukakis, P., Fluharty, D., Heneman, B., Houde, E.D., Link, J., Livingston, P.A., Mangel, M., McAllister, M.K., Pope, J., Sainsbury, K.J., 2004. Ecosystem-based fishery management. Science 305, 346-347. 
Pinnegar, J.K., Polunin, N.V.C., 1999. Differential fractionation of $\delta^{13} \mathrm{C}$ and $\delta^{15} \mathrm{~N}$ among fish tissues: implications for the study of trophic interactions. Functional Ecology 13, 225-231.

Piroddi, C., Bearzi, G., Christensen, V., 2010. Effects of local fisheries and ocean productivity on the northeastern Ionian Sea ecosystem. Ecological Modelling 221, 1526-1544. Plagànyi, E.E., 2007. Models for an ecosystem approach to fisheries. FAO Fisheries Technical Paper, Vol. 477. FAO, Rome, Italy.

Planque, B., Lazure, P., Jégou, A.M., 2004. Detecting hydrological landscapes over the Bay of Biscay continental shelf in spring. Climate Research 28, 41-52.

Polovina, J.J., 1984. Model of coral reef ecosystem I. The Ecopath model and its application to French Frigate Shoals. Coral Reefs 3, 1-11.

Polunin, N.V.C., Pinnegar, J., 2000. Trophic-level dynamics inferred from stable isotopes of carbon and nitrogen. CIESM Workshop Series 12, 69-73.

Post, D.M., 2002. Using stable isotopes to estimate trophic position: models, methods and assumptions. Ecology 83, 703-718.

Puillat, I., Lazure, P., Jégou, A.M., Lampert, L., Miller, P.I., 2004. Hydrographical variability on the French continental shelf in the Bay of Biscay, during the 1990s. Continental Shelf Research 24, 1143-1163.

$\mathrm{R}$ foundation core team, 2011. R: a language and environment for statistical computing. Vienna, Austria: R Foundation for Statistical Computing.

Roberts, D.R., Hamann, A., 2012. Method selection for species distribution modelling: are temporally or spatially independent evaluations necessary? Ecography 35, 792-802.

Rombouts, I., Beaugrand, G., Artigas, L.F., Dauvin, J.C., Gevaert, F., Goberville, E., Kopp, D., Lefebvre, S., Luczak, C., Spilmont, N., Travers-Trolet, M., Villanueva, M.C., Kirby, R.R., 2013a. Evaluating marine ecosystem health: case studies of indicators using direct observations and modelling methods. Ecological Indicators 24, 353-365. 
Rombouts, I., Beaugrand, G., Fizzala, X., Gaill, F., Greenstreet, S., Lamare, S., Le Loc'h, F., McQuatters-Gollop, A., Mialet, B., Niquil, N., Percelay, J., Renaud, F., Rossberg, A., Féral, J.P., 2013b. Food web indicators under the Marine Strategy Framework Directive: from complexity to simplicity? Ecological Indicators 29, 246-254.

Rykiel, E.J., 1996. Testing ecological models: the meaning of validation. Ecological Modelling 90, 229-244.

Sanchez, F., Olaso, I., 2004. Effects of fisheries on the Cantabrian Sea shelf ecosystem. Ecological Modelling 172, 151-174.

Shin, Y.J., Shannon, L.J., Bundy, A., Coll, M., Aydin, K.Y., Bez, N., Blanchard, J.L., Borges, M.F., Diallo, I., Diaz, E., Heymans, J.J., Hill, L., Johannesen, E., Jouffre, D., Kifani, S., Labrosse, P., Link, J.S., Mackinson, S., Masski, H., Möllmann, C., Neira, S., Ojaveer, H., ould Mohammed Abdallahi, K., Perry, I., Thiao, D., Yemane, D., Cury, P.M., 2010. Using indicators for evaluating, comparing, and communicating the ecological status of exploited marine ecosystems. 2. Setting the scene. ICES Journal of Marine Science 67, 692-716.

Spitz, J., Cherel, Y., Bertin, S., Kiszka, J., Dewez, A., Ridoux, V., 2011. Prey preferences among the community of deep-diving odontocetes from the Bay of Biscay, Northeast Atlantic. Deep Sea Research Part I: Oceanographic Research Papers 58, $273-282$.

Spitz, J., Richard, E., Meynier, L., Pusineri, C., Ridoux, V., 2006a. Dietary plasticity of the oceanic striped dolphin, Stenella coeruleoalba, in the neritic waters of the Bay of Biscay. Journal of Sea Research 55, 309-320.

Spitz, J., Rousseau, Y., Ridoux, V., 2006b. Diet overlap between harbour porpoise and bottlenose dolphin: an argument in favour of interference competition for food? Estuarine, Coastal and Shelf Science 70, 259-270. 
Tjelmeland, S., Lindstrøm, U., 2005. An ecosystem element added to the assessment of Norwegian spring-spawning herring: implementing predation by minke whales. ICES Journal of Marine Science 62, 285-294.

Ulanowicz, R.E., 1986. Growth and development: ecosystem phenomenology. SpringerVerlag, New-York, USA.

Van Oevelen, D., Soetaert, K., Middelburg, J.J., Herman, P.M.J., Moodley, L., Hamels, I., Moens, T., Heip, C.H.R., 2006. Carbon flows through a benthic food web: integrating biomass, isotope and tracer data. Journal of Marine Research 64, 453-482.

Van Valen, L., 1965. Morphological variation and width of ecological niche. The American Naturalist 99, 377-390.

Vander Zanden, M.J., Rasmussen, J.B., 1999. Primary consumer $\delta^{13} \mathrm{C}$ and $\delta^{15} \mathrm{~N}$ and the trophic position of aquatic consumers. Ecology 80, 1395-1404.

Varela, M., 1996. Phytoplankton ecology in the Bay of Biscay. Scientia Marina 60, 45-53. 
Table 1: Compartments of the Ecopath model of the French Bay of Biscay continental shelf food web used for comparison with the isotopic approach. Species column is the composition at the species level of the Ecopath functional groups. In multi-species model compartments (8-11, 17, 18), species in bold are those for which stable isotope analyses were performed and that were consequently retained in the present comparative study. Contribution is the biomass contribution of each species to their respective functional group. $T L_{E c o p a t h}$ is the trophic level derived from the Ecopath model. $T L_{S I A}$ is the trophic level estimated from stable isotope analysis for each species and $S D$ is its standard deviation, both are weighted by the biomass proportions. $S E A_{c}$ is the standard ellipse area corrected for sample size and calculated for each species. $n$ corresponds to the number of individuals analysed for stable isotope ratios. $O I$ is the omnivory index derived from the Ecopath model, indicating the degree of consumption of resources from more than one $T L . S D, S E A_{c}, O I$ and the square root of $O I$ are thus four potential estimators of trophic niche width. All the indicators used in the present study are unitless. For multi-species model compartments, the mean values of these indices, weighted by the species biomass contributions, are provided.

\begin{tabular}{|c|c|c|c|c|c|c|c|c|}
\hline Ecopath functional group & Species & Contribution & $T L_{\text {Ecopath }}$ & $T L_{S I A}$ & $S D$ & $S E A_{c}$ & $n$ & $O I$ \\
\hline 3. Striped dolphins & Stenella coeruleoalba & 100 & 4.73 & 4.72 & 0.53 & 0.88 & 11 & 0.84 \\
\hline 4. Bottlenose dolphins & Tursiops truncatus & 100 & 5.09 & 5.33 & 0.62 & 1.87 & 7 & 0.25 \\
\hline 5. Common dolphins & Delphinus delphis & 100 & 4.61 & 5.11 & 0.44 & 0.90 & 26 & 0.06 \\
\hline 6. Long-finned pilot whale & Globicephala melas & 100 & 4.65 & 4.88 & 0.54 & 2.71 & 16 & 1.91 \\
\hline 7. Harbour porpoise & Phocoena phocoena & 100 & 4.69 & 5.28 & 0.32 & 0.78 & 10 & 0.07 \\
\hline \multirow[t]{5}{*}{ 8. Piscivorous demersal fish } & & & 4.67 & 4.27 & 0.11 & 0.32 & 33 & 0.04 \\
\hline & Merluccius merluccius & 94.06 & & 4.27 & 0.11 & 0.32 & 33 & \\
\hline & Argyrosomus regius & 2.14 & & & & & & \\
\hline & Torpedo nobiliana & 3.33 & & & & & & \\
\hline & Hexanchus griseus & 0.47 & & & & & & \\
\hline \multirow{10}{*}{$\begin{array}{l}\text { 9. Piscivorous and benthivorous } \\
\text { demersal fish }\end{array}$} & & & 4.05 & 4.03 & 0.16 & 0.49 & 295 & 0.57 \\
\hline & Scyliorhinus canicula & 11.01 & & 4.46 & 0.13 & 0.16 & 10 & \\
\hline & Conger conger & 3.15 & & 4.20 & 0.29 & 1.54 & 5 & \\
\hline & Gaidropsarus vulgaris & 0.04 & & & & & & \\
\hline & Lepidorhombus boscii & 0.19 & & & & & & \\
\hline & Lepidorhombus whiffiagonis & 1.41 & & 3.86 & 0.04 & 0.06 & 5 & \\
\hline & Lophius budegassa & 1.26 & & 4.31 & 0.06 & 0.02 & 5 & \\
\hline & Lophius piscatorius & 0.86 & & 4.15 & 0.12 & 0.45 & 30 & \\
\hline & Merlangius merlangus & 1.71 & & 4.05 & 0.11 & 0.27 & 15 & \\
\hline & Trisopterus luscus & 15.20 & & 4.04 & 0.15 & 0.19 & 14 & \\
\hline
\end{tabular}




\begin{tabular}{|c|c|c|c|c|c|c|c|}
\hline Trisopterus minutus & 42.70 & & 3.94 & 0.17 & 0.65 & 65 & \\
\hline Argentina sphyraena & 4.61 & & 3.84 & 0.15 & 0.27 & 10 & \\
\hline Dicentrarchus labrax & 2.91 & & 3.82 & 0.30 & 1.09 & 11 & \\
\hline Galeorhinus galeus & 0.77 & & & & & & \\
\hline Leucoraja naevus & 4.16 & & 3.82 & 0.13 & 0.31 & 10 & \\
\hline Myliobatis aquila & 1.51 & & & & & & \\
\hline Zeus faber & 2.38 & & 4.11 & 0.08 & 0.03 & 5 & \\
\hline Spondyliosoma cantharus & 0.93 & & 4.28 & 0.27 & 0.96 & 7 & \\
\hline Squalus acanthias & 0.63 & & & & & & \\
\hline Torpedo marmorata & 0.24 & & 5.01 & 0.52 & 0.68 & 3 & \\
\hline Trachinus draco & 0.54 & & 3.73 & 0.19 & 1.66 & 10 & \\
\hline Molva molva & 0.76 & & 4.58 & $\mathbf{0 . 0 7}$ & 0.04 & 4 & \\
\hline Molva dypterygia & 0.11 & & & & & & \\
\hline Chelidonichthys gurnardus & 0.33 & & 3.86 & 0.15 & 0.47 & 18 & \\
\hline Mustelus asterias & 0.68 & & 3.85 & 0.30 & 0.90 & 11 & \\
\hline Pollachius pollachius & 0.41 & & & & & & \\
\hline Melanogrammus aeglefinus & 0.13 & & 3.93 & 0.39 & 0.85 & 5 & \\
\hline Chelidonichthys lucerna & 0.08 & & 3.81 & 0.18 & 0.68 & 5 & \\
\hline Mustelus mustelus & 0.14 & & 4.04 & 0.28 & 0.57 & 4 & \\
\hline Galeus melastomus & $\mathbf{0 . 0 3}$ & & 4.36 & 0.15 & 0.21 & 12 & \\
\hline Dasyatis pastinaca & 0.06 & & & & & & \\
\hline Dicentrarchus punctatus & 0.11 & & 3.98 & 0.20 & 0.10 & 4 & \\
\hline Diplodus vulgaris & 0.06 & & & & & & \\
\hline Echiichthys vipera & 0.05 & & 3.90 & 0.11 & 0.16 & 5 & \\
\hline Helicolenus dactylopterus & $\mathbf{0 . 0 3}$ & & 4.09 & $\mathbf{0 . 0 7}$ & 0.12 & 5 & \\
\hline Hyperoplus lanceolatus & 0.04 & & 3.99 & 0.11 & 0.26 & 5 & \\
\hline Labrus mixtus & 0.03 & & & & & & \\
\hline Lithognathus mormyrus & 0.12 & & & & & & \\
\hline Pagellus acarne & 0.20 & & & & & & \\
\hline Pagellus bogaraveo & 0.14 & & & & & & \\
\hline Phycis blennoides & 0.10 & & 4.04 & 0.14 & 0.15 & 5 & \\
\hline \multirow[t]{2}{*}{ Scophthalmus maximus } & 0.15 & & & & & & \\
\hline & & 3.49 & 3.88 & 0.26 & 1.00 & 160 & 0.11 \\
\hline
\end{tabular}




$\begin{array}{ll}\text { Capros aper } & 15.32 \\ \text { Micromesistius poutassou } & \mathbf{8 1 . 3 6} \\ \text { Argentina silus } & \mathbf{0 . 0 2} \\ \text { Boops boops } & \mathbf{0 . 4 0} \\ \text { Cepola macrophthalma } & \mathbf{0 . 1 6} \\ \text { Ammodytes tobianus } & \mathbf{0 . 1 0} \\ \text { Aphia minuta } & 0.02 \\ \text { M. merluccius juveniles } & \mathbf{2 . 6 3}\end{array}$

11. Benthivorous demersal fish

Arnoglossus laterna

Arnoglossus imperialis

Arnoglossus thori

Callionymus lyra

Microchirus variegatus

Solea solea

Chelidonichthys cuculus

Liza ramada

Balistes carolinensis

Enchelyopus cimbrius

Mullus surmuletus

Raja clavata

Raja montagui

Sparus auratus

Microstomus kitt

Callionymus maculatus

Buglossidium luteum

Chelidonichthys obscurus

Dicologlossa cuneata

Lesueurigobius friesii

Leucoraja circularis

Pomatoschistus minutus

Syngnathus acus

Umbrina canariensis
15.32

0.02

0.40

0.16

0.10

2.63

3.38

10.36

0.09

6.40

15.47

30.57

6.69

9.85

1.64

1.26

3.73

4.04

1.77

2.22

0.53

0.27

0.12

0.19

0.49

0.15

0.24

0.19

0.17

0.18 $\begin{array}{llll}3.87 & 0.26 & 1.01 & 83\end{array}$

$\begin{array}{llll}3.63 & 0.11 & 0.25 & 5\end{array}$

$\begin{array}{llll}3.98 & 0.40 & 2.58 & 5\end{array}$

$\begin{array}{llll}4.13 & 0.13 & 0.30 & 5\end{array}$

$\begin{array}{llll}3.68 & 0.09 & 0.13 & 5\end{array}$

$\begin{array}{llll}4.16 & 0.16 & 0.59 & 57\end{array}$

$\begin{array}{lllll}3.41 & 3.54 & 0.21 & 0.72 & 73\end{array}$

0.39

$\begin{array}{llll}3.54 & 0.11 & 0.25 & 5\end{array}$

$\begin{array}{llll}3.75 & 0.06 & 0.02 & 5\end{array}$

$\begin{array}{llll}3.31 & 0.32 & 1.29 & 27\end{array}$

$\begin{array}{llll}3.97 & 0.12 & 0.34 & 10\end{array}$

$\begin{array}{llll}3.72 & 0.27 & 0.46 & 11\end{array}$

$\begin{array}{llll}3.80 & 0.22 & 0.81 & 5\end{array}$

$\begin{array}{llll}3.95 & 0.14 & 0.17 & 5\end{array}$

$\begin{array}{llll}4.03 & 0.11 & 0.13 & 5\end{array}$ 
12. Mackerel

13. Horse mackerel

14. Anchovy

15. Sardine

16. Sprat

17. Benthic cephalopods

\section{Octopus vulgaris}

Rossia macrosoma

Sepia elegans

Sepia officinalis

Sepia orbignyana

Eledone cirrhosa

18. Pelagic cephalopods

\section{Allotheutis spp.}

Illex coindetii

Loligo forbesii

Loligo vulgaris

Todarodes sagittatus

Todaropsis eblanae

$\begin{array}{lllllll}100 & 3.75 & 4.06 & 0.25 & 0.81 & 10 & 0.12 \\ 100 & 3.69 & 4.03 & 0.17 & 0.56 & 45 & 0.09 \\ 100 & 3.67 & 3.74 & 0.18 & 1.13 & 46 & 0 \\ 100 & 3.44 & 3.79 & 0.24 & 1.00 & 78 & 0.28 \\ 100 & 3.67 & 4.01 & 0.24 & 0.35 & 32 & 0\end{array}$

10.31

0.43

22.14

39.12

6.48

21.51

$$
3.71
$$

3.42

0.23

1.01

130

0.32

3.140 .28

$3.17 \quad 0.06$

$3.46 \quad 0.17$

3.56

0.30

$\begin{array}{ll}0.27 & 7\end{array}$

3.35

3.28

0.11

0.4625

$1.59 \quad 42$

$0.41 \quad 10$

$\begin{array}{lll}0.19 & 0.78 & 41\end{array}$

4.45

13.46

16.35

19.60

46.67

0.40

3.52

\begin{tabular}{lllll}
3.89 & 0.15 & 0.76 & 185 & 0.36 \\
$\mathbf{3 . 8 8}$ & $\mathbf{0 . 1 1}$ & $\mathbf{0 . 1 7}$ & $\mathbf{1 3}$ & \\
$\mathbf{3 . 9 1}$ & $\mathbf{0 . 1 1}$ & $\mathbf{0 . 3 1}$ & $\mathbf{3 2}$ & \\
$\mathbf{3 . 9 7}$ & $\mathbf{0 . 2 0}$ & $\mathbf{1 . 3 2}$ & $\mathbf{3 8}$ & \\
$\mathbf{3 . 8 5}$ & $\mathbf{0 . 1 6}$ & $\mathbf{0 . 8 6}$ & $\mathbf{4 7}$ & \\
$\mathbf{3 . 8 3}$ & $\mathbf{0 . 1 1}$ & $\mathbf{0 . 5 5}$ & $\mathbf{3 6}$ & \\
$\mathbf{4 . 0 5}$ & $\mathbf{0 . 1 5}$ & $\mathbf{0 . 6 1}$ & $\mathbf{1 9}$ & \\
\hline
\end{tabular}


Table 2: Agreement between TLs estimates in previous studies. $\mathrm{r}^{2}$ is the coefficient of determination. In bold were given those values that were retained in the intersite comparison.

\begin{tabular}{lll}
\hline Study area & $\mathrm{r}^{2}$ & References \\
\hline Continental shelf of the Bay of Biscay & $\mathbf{0 . 7 2}$ & Present study \\
Prince William Sound & $\mathbf{0 . 9 7}$ & Kline and Pauly (1998) \\
Worldwide marine mammals & Not different from 0 (agreement not assessed within a single site) & Pauly et al. (1998b) \\
Salt marsh ponds in Virginia (USA) & No coefficient and numerical data provided & Dame and Christian (2008) \\
Fjord in northern Norway & $\mathbf{0 . 7 2}$ & Nilsen et al. (2008) \\
South tropical lagoon & $\mathbf{0 . 8 2}$ & Milessi et al. (2010) \\
South Catalan Sea & 0.48 (between $T L s$ of Ecopath and $\delta^{15} \mathrm{~N}$ values) & Navarro et al. (2011) \\
\hline
\end{tabular}




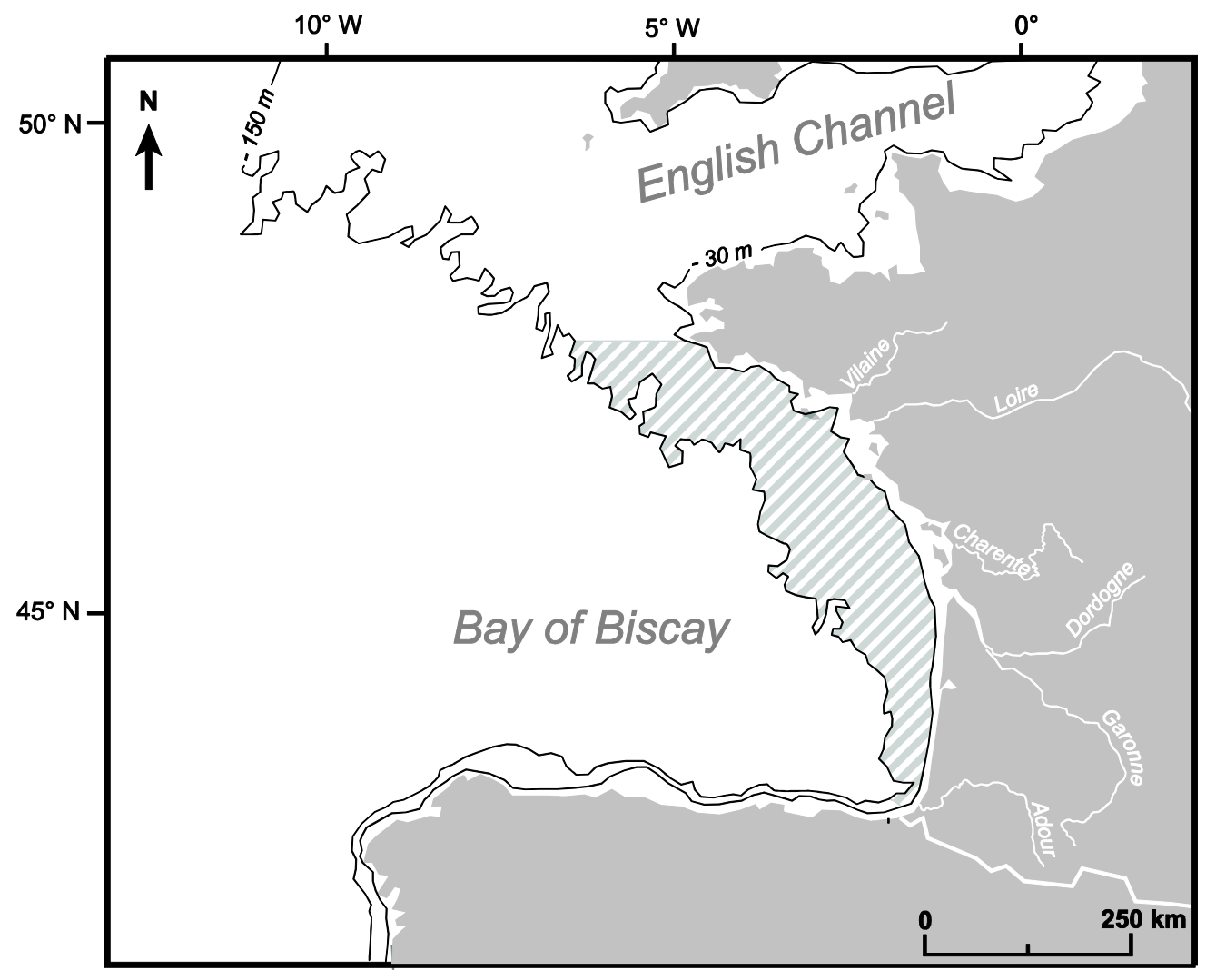

Fig. 1. Study area of the Bay of Biscay continental shelf and locations of the main rivers flowing into it. The shaded area corresponds to the French part of the continental shelf. 


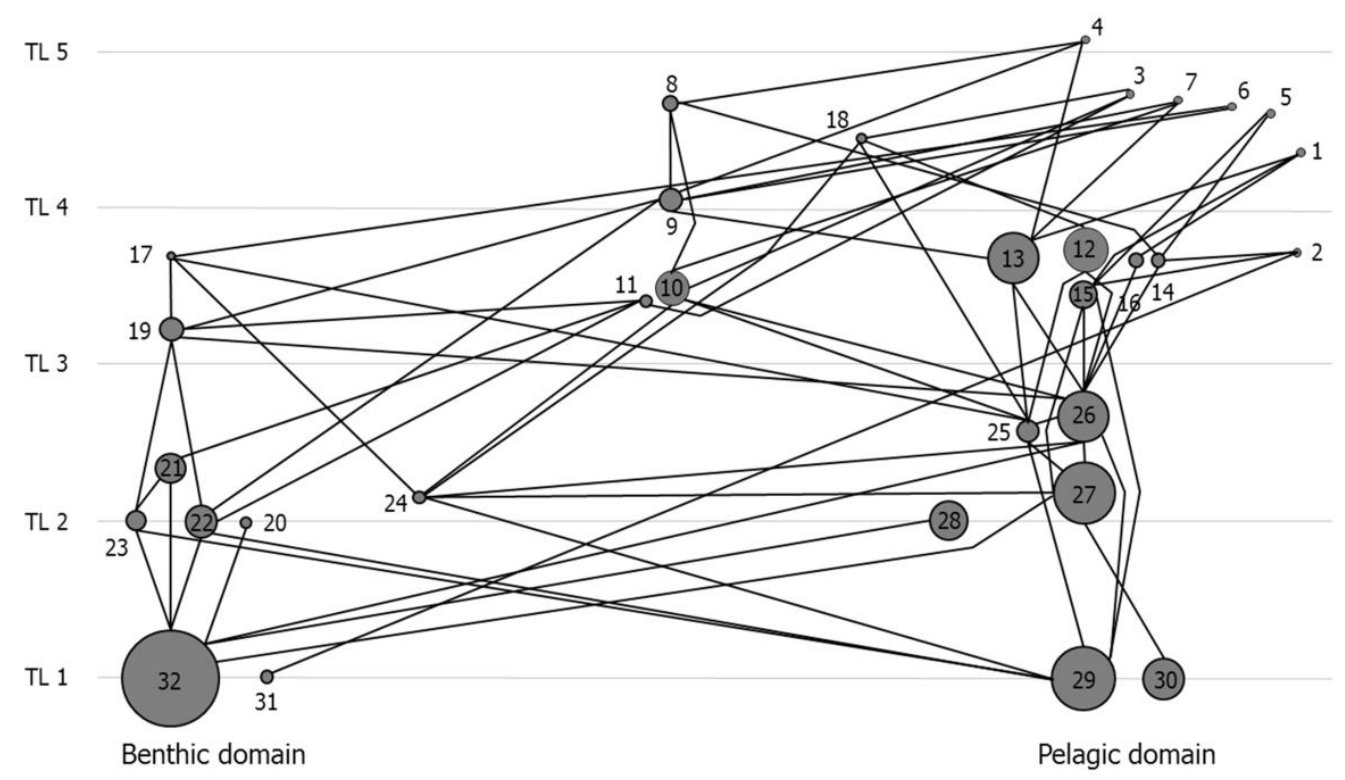

1. Plunge and pursuit diver seabirds; 2. Surface feeder seabirds; 3. Striped dolphin Stenella coeruleoalba; 4. Bottlenose dolphin Tursiops truncatus; 5 . Common dolphin Delphinus delphis; 6. Long-finned pilot whale Globicephala melas; 7. Harbour porpoise Phocoena phocoena; 8. Piscivorous demersal fish; 9. Piscivorous and benthivorous demersal fish; 10. Suprabenthivorous demersal fish; 11. Benthivorous demersal fish; 12. Mackerel Scomber scombrus; 13. Horse mackerel Trachurus trachurus; 14. Anchovy Engraulis encrasicolus; 15. Sardine Sardina pilchardus; 16. Sprat Sprattus sprattus; 17. Benthic cephalopods; 18. Pelagic cephalopods; 19. Carnivorous benthic invertebrates; 20. Necrophagous benthic invertebrates; 21. Sub-surface deposit feeder invertebrates; 22. Surface suspension and deposit feeder invertebrates; 23. Benthic meiofauna; 24. Suprabenthic invertebrates; 25 . Macrozooplankton ( $\geq 2 \mathrm{~mm}) ; 26$. Mesozooplankton $(0.2-2 \mathrm{~mm}) ; 27$. Microzooplankton $(\leq 0.2 \mathrm{~mm}) ; 28$. Bacteria; 29. Large phytoplankton $(\geq 3 \mu \mathrm{m}) ; 30$. Small phytoplankton $(<3 \mu \mathrm{m}) ; 31$. Fishery discards; 32 . Pelagic detritus

Fig. 2. Trophic model of the Bay of Biscay continental shelf (from Lassalle et al., 2011). Boxes are arranged using trophic level $(T L)$ as the y-axis and benthic/pelagic partitioning as the x-axis. Only the links to the three most important diets are represented for each functional group. The size of each box is proportional to the biomass it represents. 


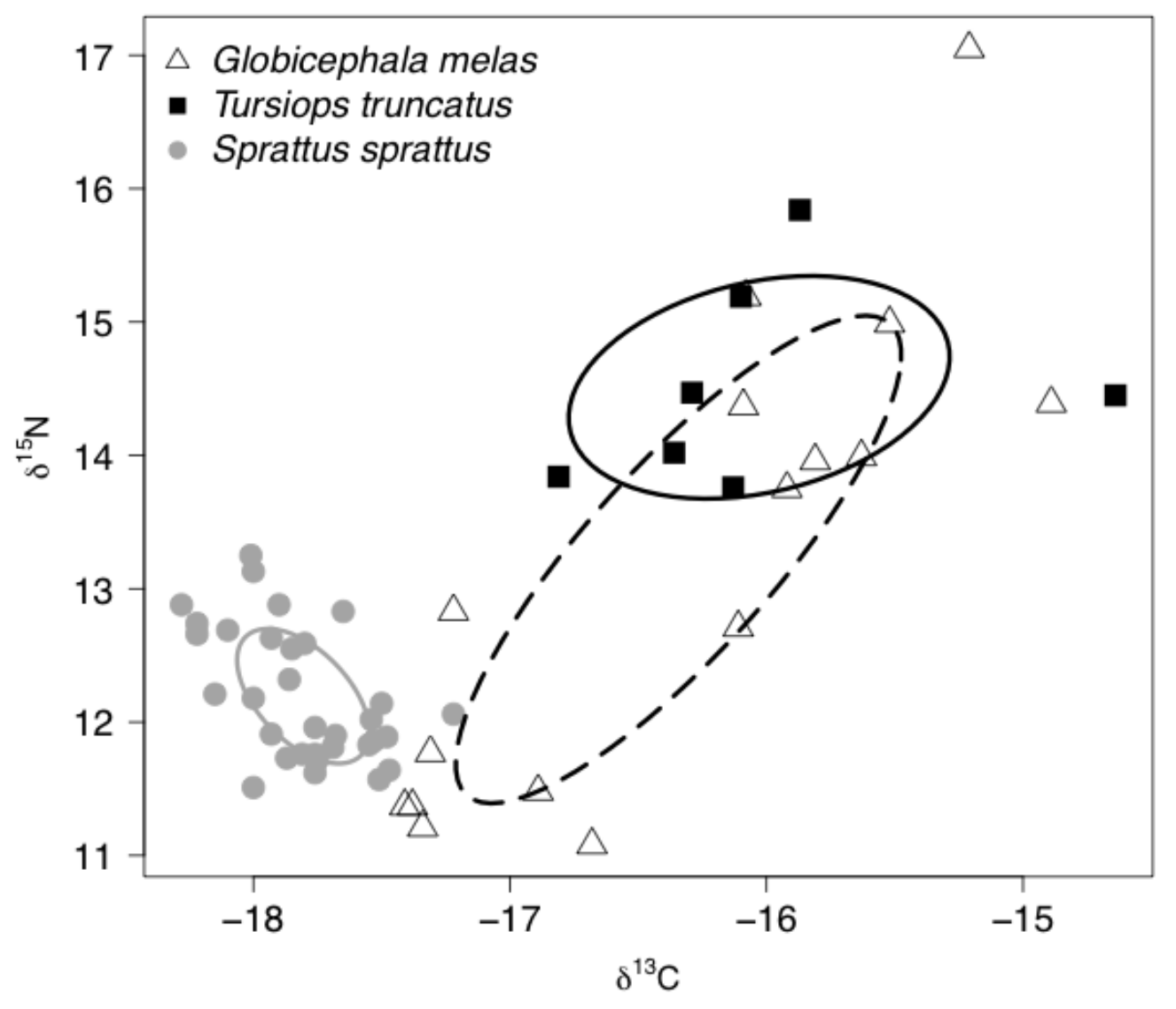

Fig. 3. Stable isotope bi-plots (sample data in $\delta^{13} \mathrm{C}$ and $\delta^{15} \mathrm{~N}$ bivariate space) illustrating the isotopic niche of (a) bottlenose dolphins (Tursiops truncatus), (b) long-finned pilot whales (Globicephala melas), and (c) sprats (Sprattus sprattus). For each species, individuals are represented by circles and a solid line encloses its corrected standard ellipse area $\left(\mathrm{SEA}_{\mathrm{c}}\right)$. 


\section{Trophic level}

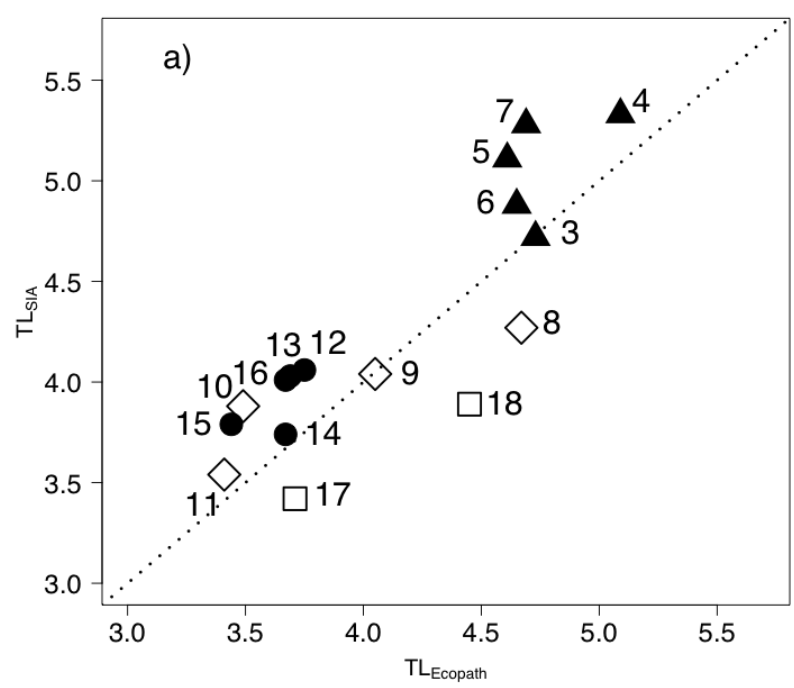

Trophic niche width
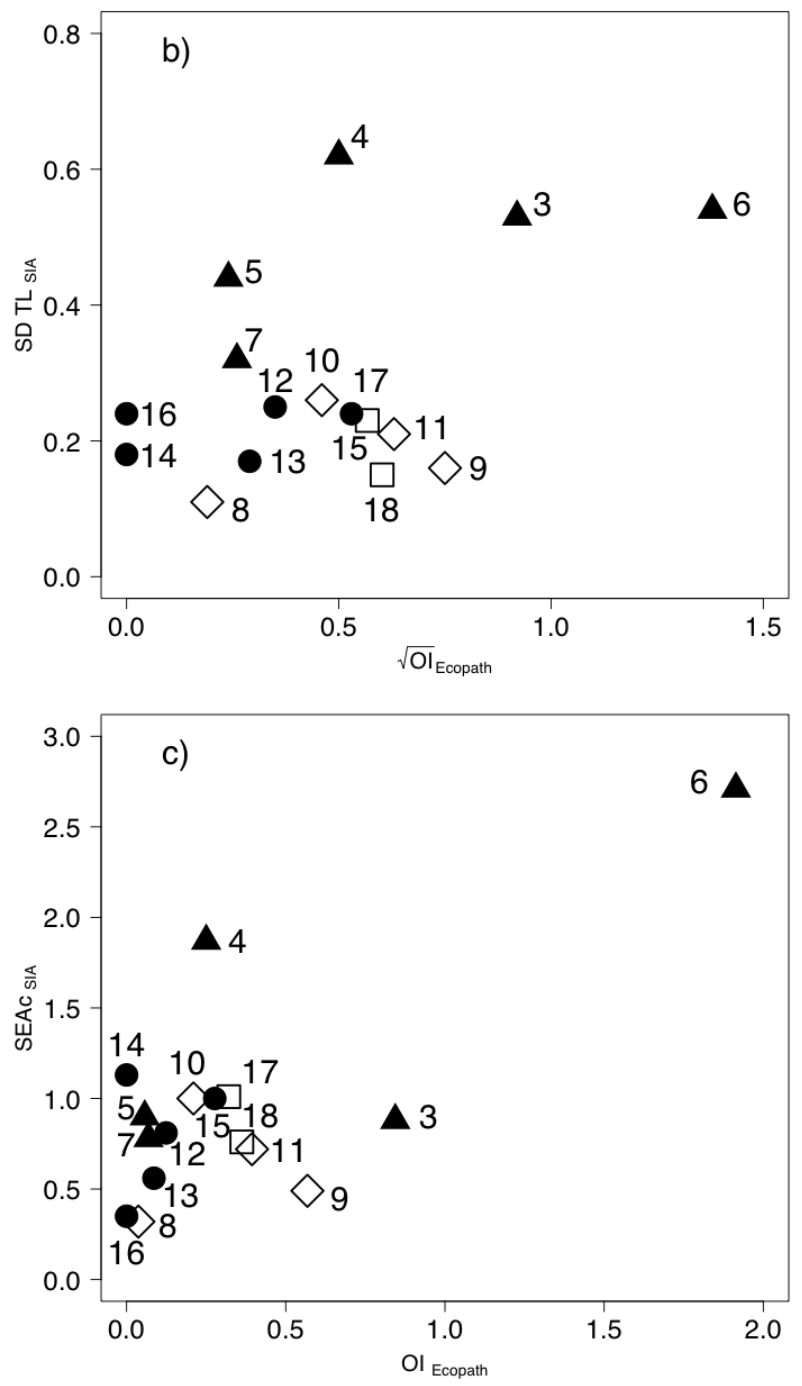

Fig. 4. (a) $T L s$ estimated from stable isotopes $\left(T L_{S I A}\right)$ plotted against their corresponding levels estimated by the Ecopath model ( $\left.T L_{\text {Ecopath }}\right)$ for the French Bay of Biscay continental shelf food web; (b) standard deviations $(S D)$ of $T L s$ estimated from SIA plotted against the corresponding square root of $O I$ derived from the Ecopath model; (c) corrected standard ellipse areas $\left(S E A_{c}\right)$ estimated from SIA plotted against the corresponding $O I$ values. Different symbols are used to depict mono- 
specific functional groups of marine mammals (black triangles), mono-specific functional groups of small pelagic fish (black circles), multi-specific functional groups of demersal fish (white diamonds) and multi-specific functional groups of cephalopods (white squares). Code corresponding to the names of functional groups is given in Table 1. Where the Spearman-rank correlation coefficient is significant, the 1:1 line of perfect agreement is shown by a broken line. 
Supplementary material 1: a detailed description of the main equations of the Ecopath model.

Ecopath model parameterization is based on two "master" equations. One decomposes the production term of each compartment (species or group of species with similar ecotrophic role) (Christensen and Walters, 2004; Christensen et al., 2008):

Production $=$ fishery catch + predation mortality + net migration + biomass accumulation + other mortality (1).

"Other mortality" includes natural mortality factors such as mortality due to senescence, diseases, etc.

The other equation describes the energy balance of each group:

Consumption $=$ production + respiration + unassimilated food $(2)$.

More formally, the equations can be written as follows for a group $i$ and its predator $j$ :

$B_{i} \times(P / B)_{i}=Y_{i}+\sum_{j}\left(B_{j} \times(Q / B)_{j} \times D C_{i j}\right)+E x_{i}+B a c c_{i}+B_{i}\left(1-E E_{i}\right) \times(P / B)_{i}$

and

$B_{i} \times(Q / B)_{i}=B_{i} \times(P / B)_{i}+R_{i}+U_{i}$

where the main input parameters are biomass density $\left(B\right.$, here in $\mathrm{kg} \mathrm{C} \cdot \mathrm{km}^{-2}$ or tons $\left.\mathrm{km}^{-2}\right)$, production rate $\left(P / B\right.$, year $\left.{ }^{-1}\right)$, consumption rate $\left(Q / B\right.$, year $\left.{ }^{-1}\right)$, proportion of $i$ in the diet of $j\left(D C_{i j}\right.$; $D C=$ diet composition $)$, net migration rate $\left(E x\right.$, year $\left.^{-1}\right)$, biomass accumulation $\left(\right.$ Bacc, year $\left.{ }^{-1}\right)$, total

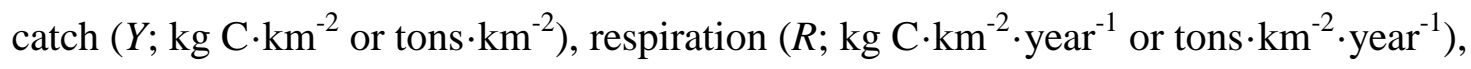
unassimilated food rate $(U)$ and ecotrophic efficiency $(E E$; amount of species production used within the system). The "other mortality" term, $M O$, is internally computed from:

$M 0_{i}=B_{i}\left(1-E E_{i}\right) \times(P / B)_{i}$ 
Supplementary Table 1: Predator/prey matrix (column/raw). The fraction of one compartment consumed by another is expressed as the fraction of the total diet, the sum of each column being equal to one. $T L_{\text {Ecopath }}$ : trophic level derived from Ecopath.

\begin{tabular}{|c|c|c|c|c|c|c|c|c|c|c|c|c|c|c|c|}
\hline & $T \mathrm{~L}_{\text {Ecopath }}$ & 1. & 2. & 3. & 4. & 5. & 6. & 7. & 8. & 9. & 10. & 11. & 12. & 13. & 14. \\
\hline 1. Plunge and pursuit divers seabirds & 4.36 & & & & & & & & & & & & & & \\
\hline 2. Surface feeders seabirds & 3.72 & & & & & & & & & & & & & & \\
\hline 3. Striped dolphins Stenella coeruleoalba & 4.73 & & & & & & & & & & & & & & \\
\hline 4. Bottlenose dolphins Tursiops truncatus & 5.09 & & & & & & & & & & & & & & \\
\hline 5. Common dolphins Delphinus delphis & 4.61 & & & & & & & & & & & & & & \\
\hline 6. Long-finned pilot whale Globicephala melas & 4.65 & & & & & & & & & & & & & & \\
\hline 7. Harbour porpoise Phocoena phocoena & 4.69 & & & & & & & & & & & & & & \\
\hline 8. Piscivorous demersal fish & 4.67 & & & 0.014 & 0.335 & 0.015 & 0.002 & 0.011 & & & & & & & \\
\hline 9. Piscivorous and benthivorous demersal fish & 4.05 & & & 0.097 & 0.169 & 0.031 & 0.085 & 0.240 & 0.150 & 0.040 & & 0.010 & & & \\
\hline 10. Suprabenthivorous demersal fish & 3.49 & 0.100 & & 0.345 & 0.081 & 0.004 & 0.006 & 0.216 & 0.180 & 0.055 & 0.005 & 0.030 & 0.017 & 0.010 & \\
\hline 11. Benthivorous demersal fish & 3.41 & & & 0.148 & 0.125 & 0.032 & & 0.012 & 0.050 & 0.010 & & 0.010 & & & \\
\hline 12. Mackerel Scomber scombrus & 3.75 & 0.090 & 0.070 & & 0.023 & 0.056 & 0.004 & 0.009 & 0.100 & 0.09 & 0.005 & & 0.033 & 0.005 & \\
\hline 13. Horse mackerel Trachurus trachurus & 3.69 & 0.140 & 0.070 & & 0.132 & 0.050 & 0.039 & 0.276 & 0.220 & 0.135 & 0.005 & 0.020 & 0.030 & 0.005 & \\
\hline 14. Anchovy Engraulis encrasicolus & 3.67 & 0.070 & 0.130 & 0.002 & 0.002 & 0.226 & & 0.003 & 0.130 & 0.022 & 0.005 & & 0.011 & 0.005 & \\
\hline 15. Sardine Sardina pilchardus & 3.44 & 0.380 & 0.210 & & 0.031 & 0.449 & 0.006 & 0.213 & 0.115 & 0.040 & 0.005 & & 0.009 & 0.007 & \\
\hline 16. Sprat Sprattus sprattus & 3.67 & 0.140 & 0.110 & & 0.009 & 0.080 & & & 0.055 & 0.018 & 0.005 & & 0.007 & 0.005 & \\
\hline 17. Benthic cephalopods & 3.71 & & & 0.006 & & 0.032 & 0.243 & 0.009 & & 0.010 & 0.002 & 0.003 & & & \\
\hline 18. Pelagic cephalopods & 4.45 & & & 0.122 & 0.093 & 0.025 & 0.006 & 0.008 & & 0.005 & 0.003 & 0.007 & 0.005 & 0.010 & \\
\hline 19. Carnivorous benthic invertebrates & 3.23 & & & & & & & & & 0.275 & & 0.200 & & 0.020 & \\
\hline 20. Necrophagous benthic invertebrates & 2 & & & & & & & & & 0.020 & & 0.050 & & & \\
\hline 21. Sub-surface deposit feeders invertebrates & 2.34 & & & & & & & & & 0.030 & & 0.120 & & & \\
\hline 22. Surface suspension and deposit feeders inv. & 2 & & & & & & & & & 0.220 & & 0.540 & & & \\
\hline 23. Benthic meiofauna & 2 & & & & & & & & & & & & & & \\
\hline 24. Suprabenthic invertebrates & 2.14 & & & & & & & & & 0.010 & 0.038 & & & 0.010 & \\
\hline 25. Macrozooplankton $(\geq 2 \mathrm{~mm})$ & 2.57 & & 0.120 & & & & 0.050 & & & & 0.175 & & 0.200 & 0.150 & \\
\hline 26. Mesozooplankton $(0.2-2 \mathrm{~mm})$ & 2.67 & & & & & & & & & & 0.410 & & 0.655 & 0.723 & 1 \\
\hline 27. Microzooplankton $(\leq 0.2 \mathrm{~mm})$ & 2.18 & & & & & & & & & & & & 0.033 & 0.050 & \\
\hline 28. Bacteria & 2 & & & & & & & & & & & & & & \\
\hline 29. Large phytoplankton $(\geq 3 \mu \mathrm{m})$ & 1 & & & & & & & & & & & & & & \\
\hline 30. Small phytoplankton $(<3 \mu \mathrm{m})$ & 1 & & & & & & & & & & & & & & \\
\hline 31. Discards & 1 & 0.080 & 0.290 & & & & & & & 0.020 & & 0.010 & & & \\
\hline 32. Pelagic detritus & 1 & & & & & & & & & & & & & & \\
\hline Import & & & & 0.266 & & & 0.559 & 0.003 & & & & & & & \\
\hline
\end{tabular}


Table 1: (continued)

1. Plunge and pursuit divers seabirds $\quad 4.36$

2. Surface feeders seabirds $\quad 3.72$

3. Striped dolphins Stenella coeruleoalba 4.73

4. Bottlenose dolphins Tursiops truncatus $\quad 5.09$

5. Common dolphins Delphinus delphis 4.61

6. Long-finned pilot whale Globicephala melas 4.65

7. Harbour porpoise Phocoena phocoena 4.69

8. Piscivorous demersal fish 4.67

9. Piscivorous and benthivorous demersal fish 4.05

10. Suprabenthivorous demersal fish $\quad 3.49$

11. Benthivorous demersal fish 3.41

12. Mackerel Scomber scombrus $\quad 3.75$

13. Horse mackerel Trachurus trachurus $\quad 3.69$

14. Anchovy Engraulis encrasicolus $\quad 3.67$

15. Sardine Sardina pilchardus $\quad 3.44$

16. Sprat Sprattus sprattus $\quad 3.67$

17. Benthic cephalopods $\quad 3.71$

18. Pelagic cephalopods $\quad 4.45$

19. Carnivorous benthic invertebrates 3.23

20. Necrophagous benthic invertebrates 2

21. Sub-surface deposit feeders invertebrates $\quad 2.34$

22. Surface suspension and deposit feeders inv. 2

23. Benthic meiofauna 2

24. Suprabenthic invertebrates $\quad 2.14$

25. Macrozooplankton $(\geq 2 \mathrm{~mm}) \quad 2.57$

26. Mesozooplankton $(0.2-2 \mathrm{~mm})$

27. Microzooplankton $(\leq 0.2 \mathrm{~mm})$

21. 22. 23. 24. 25. 26. 27.28

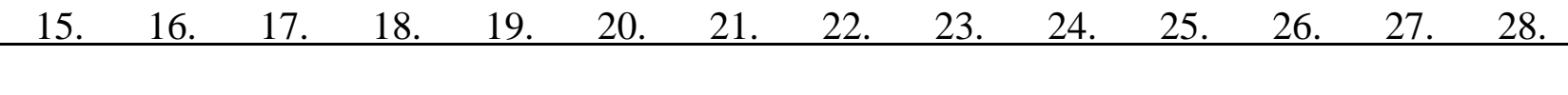

28. Bacteria

29. Large phytoplankton $(\geq 3 \mu \mathrm{m})$

30. Small phytoplankton $(<3 \mu \mathrm{m})$

31. Discards

32. Pelagic detritus

Import

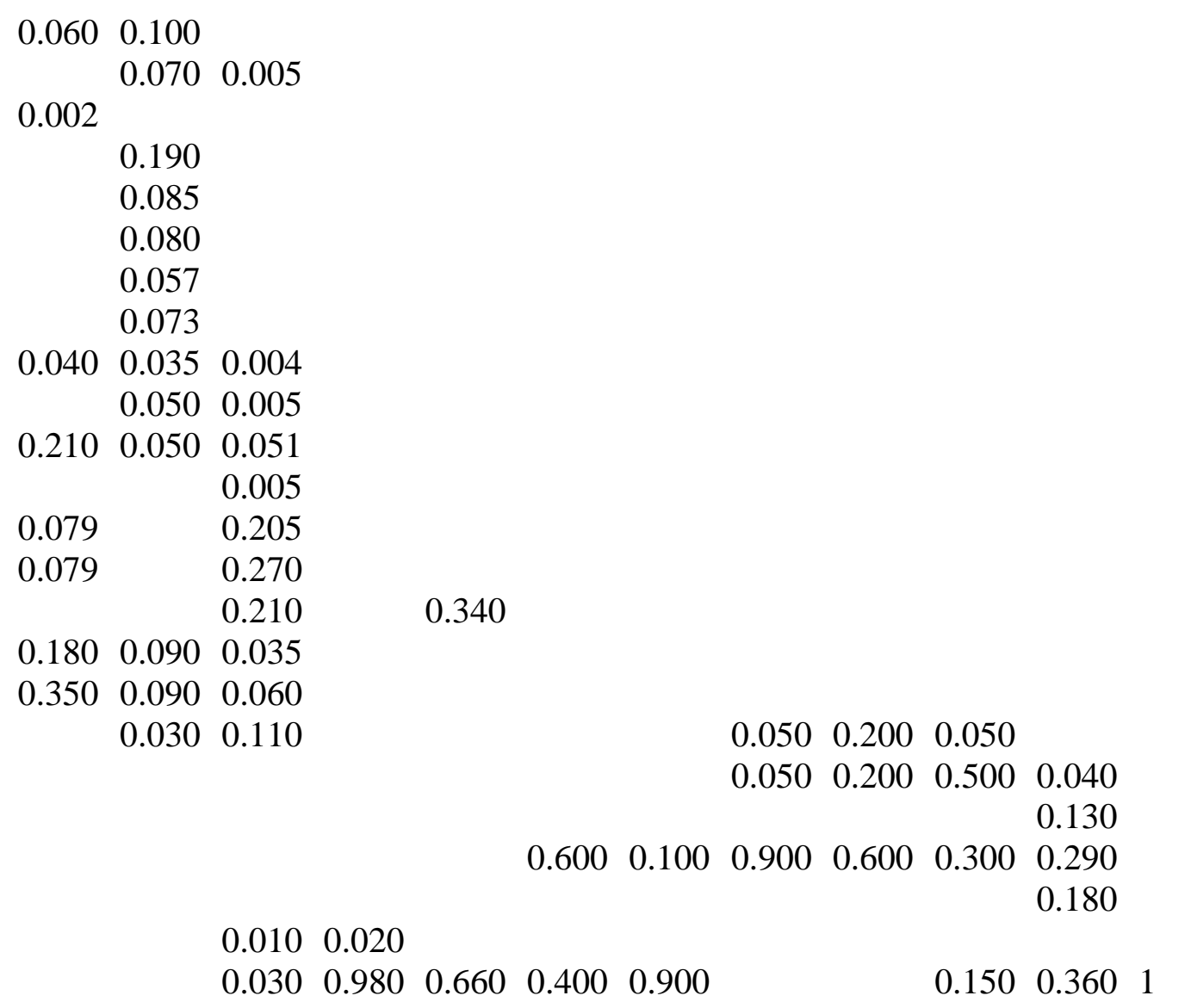


Supplementary Table 2: Stable isotope values (\%o) of carbon $\left(\delta^{13} \mathrm{C}\right)$ and nitrogen $\left(\delta^{15} \mathrm{~N}\right)$ at the species and functional group levels. The full list of species composing multi-species model compartments $(8-11,17,18)$ is given; species in bold are those for which stable isotope analyses were performed and that were consequently retained in the present comparative study. The mean isotope ratios weighted by species biomass contributions are also given for multi-species model compartments. $n$ corresponds to the number of individuals analysed for stable isotope ratios. Contribution is the biomass contribution of each species to their respective functional group.

Ecopath functional group

3. Striped dolphins

4. Bottlenose dolphins

5. Common dolphins

6. Long-finned pilot whale

7. Harbour porpoise

8. Piscivorous demersal fish

\section{Merluccius merluccius}

9. Piscivorous and benthivorous demersal fish
Argyrosomus regius

Torpedo nobiliana

Hexanchus griseus

Species
Stenella coeruleoalba
Tursiops truncatus
Delphinus delphis
Globicephala melas
Phocoena phocoena

Merluccius merluccius
Argyrosomus regius
Torpedo nobiliana
Hexanchus griseus

\section{Scyliorhinus canicula}

Conger conger

Gaidropsarus vulgaris

Lepidorhombus boscii

Lepidorhombus whiffiagonis

Lophius budegassa

Lophius piscatorius

Merlangius merlangus

Trisopterus luscus

Contrib
100
100
100
100
100

$\mathbf{9 4 . 0 6}$
2.14
3.33
0.47

94.06

3.33

0.47

$$
-16.9 \pm 0.3 \quad 13.4 \pm 0.5
$$

$\begin{array}{llll}11.01 & 10 & -16.7 \pm 0.2 & 13.1 \pm 0.3\end{array}$

$\begin{array}{llll}11.01 & 5 & -16.2 \pm 0.6 & 15.3 \pm 0.7\end{array}$

0.04

0.19

1.41

1.26

0.86

1.71

15.20
$5 \quad-17.5 \pm 0.2 \quad 12.2 \pm 0.2$

$5 \quad-17.2 \pm 0.1 \quad 14.0 \pm 0.3$

$30 \quad-17.0 \pm 0.4 \quad 14.0 \pm 0.6$

$14 \quad-16.6 \pm 0.3 \quad 14.1 \pm 0.2$
$15 \quad-16.2 \pm 0.3 \quad 14.8 \pm 0.4$ 


$\begin{array}{ll}\text { Trisopterus minutus } & \mathbf{4 2 . 7 0} \\ \text { Argentina sphyraena } & \mathbf{4 . 6 1} \\ \text { Dicentrarchus labrax } & \mathbf{2 . 9 1} \\ \text { Galeorhinus galeus } & 0.77 \\ \text { Leucoraja naevus } & \mathbf{4 . 1 6} \\ \text { Myliobatis aquila } & 1.51 \\ \text { Zeus faber } & \mathbf{2 . 3 8} \\ \text { Spondyliosoma cantharus } & \mathbf{0 . 9 3} \\ \text { Squalus acanthias } & 0.63 \\ \text { Torpedo marmorata } & \mathbf{0 . 2 4} \\ \text { Trachinus draco } & \mathbf{0 . 5 4} \\ \text { Molva molva } & \mathbf{0 . 7 6} \\ \text { Molva dypterygia } & 0.11 \\ \text { Chelidonichthys gurnardus } & \mathbf{0 . 3 3} \\ \text { Mustelus asterias } & \mathbf{0 . 6 8} \\ \text { Pollachius pollachius } & 0.41 \\ \text { Melanogrammus aeglefinus } & \mathbf{0 . 1 3} \\ \text { Chelidonichthys lucerna } & \mathbf{0 . 0 8} \\ \text { Mustelus mustelus } & \mathbf{0 . 1 4} \\ \text { Galeus melastomus } & \mathbf{0 . 0 3} \\ \text { Dasyatis pastinaca } & 0.06 \\ \text { Dicentrarchus punctatus } & \mathbf{0 . 1 1} \\ \text { Diplodus vulgaris } & 0.06 \\ \text { Echiichthys vipera } & \mathbf{0 . 0 5} \\ \text { Helicolenus dactylopterus } & \mathbf{0 . 0 3} \\ \text { Hyperoplus lanceolatus } & \mathbf{0 . 0 4} \\ \text { Labrus mixtus } & 0.03 \\ \text { Lithognathus mormyrus } & 0.12 \\ \text { Pagellus acarne } & 0.20 \\ \text { Pagellus bogaraveo } & 0.14 \\ \text { Phycis blennoides } & \mathbf{0 . 1 0} \\ \text { Scophthalmus maximus } & 0.15 \\ & \end{array}$

\begin{tabular}{|c|c|c|}
\hline 65 & $-17.1 \pm 0.4$ & $13.1 \pm 0.6$ \\
\hline 10 & $-17.4 \pm 0.2$ & $12.3 \pm 0.4$ \\
\hline 11 & $-16.3 \pm 0.7$ & $14.1 \pm 0.5$ \\
\hline 10 & $-16.3 \pm 0.3$ & $12.3 \pm 0.3$ \\
\hline 5 & $-16.8 \pm 0.1$ & $14.0 \pm 0.3$ \\
\hline 7 & $-16.5 \pm 0.6$ & $15.1 \pm 0.5$ \\
\hline 3 & $-16.4 \pm 0.5$ & $14.8 \pm 0.5$ \\
\hline 10 & $-16.7 \pm 0.8$ & $13.0 \pm 1.3$ \\
\hline 4 & $-17.5 \pm 0.3$ & $14.5 \pm 0.3$ \\
\hline 18 & $-16.9 \pm 0.3$ & $13.1 \pm 0.5$ \\
\hline 11 & $-15.9 \pm 0.5$ & $13.0 \pm 0.6$ \\
\hline 5 & $-17.4 \pm 0.2$ & $12.6 \pm 1.3$ \\
\hline 5 & $-16.8 \pm 0.6$ & $13.2 \pm 0.5$ \\
\hline 4 & $-16.1 \pm 0.4$ & $13.0 \pm 0.3$ \\
\hline 12 & $-17.2 \pm 0.2$ & $12.1 \pm 0.6$ \\
\hline 4 & $-16.7 \pm 0.0$ & $13.9 \pm 0.6$ \\
\hline 5 & $-17.5 \pm 0.2$ & $12.3 \pm 0.2$ \\
\hline 5 & $-17.3 \pm 0.1$ & $13.2 \pm 0.3$ \\
\hline 5 & $-16.4 \pm 0.3$ & $14.3 \pm 0.3$ \\
\hline 5 & $-17.0 \pm 0.3$ & $13.5 \pm 0.1$ \\
\hline
\end{tabular}


Micromesistius poutassou

Argentina silus

Boops boops

Cepola macrophthalma

Ammodytes tobianus

Aphia minuta

M. merluccius juveniles

11. Benthivorous demersal fish
81.36

0.02

0.40

0.16

0.10

0.02

2.63

3.38

10.36

0.09

6.40

15.47

30.57

6.69

9.85

1.64

1.26

3.73

$\mathbf{4 . 0 4}$

1.77

2.22

0.53

0.27

0.12

0.19

0.49

0.15

0.24

0.19

0.17

0.18

Umbrina canariensis

Scomber scombrus

Trachurus trachurus

100

100
$83 \quad-18.2 \pm 0.5$

$-18.1 \pm 0.2$

$-18.0 \pm 0.6$

$-18.2 \pm 0.3$

$-17.1 \pm 0.2$

$57 \quad-18.1 \pm 0.4$

$-16.4 \pm 0.4$

$5 \quad-16.6 \pm 0.3$

$5 \quad-17.3 \pm 0.0$

$12.5 \pm 0.3$

$12.2 \pm 0.1$

$27 \quad-15.7 \pm 0.6$

$13.2 \pm 0.7$

$10-17.2 \pm 0.3$

$13.1 \pm 0.6$

$11-16.1 \pm 0.4 \quad 12.3 \pm 0.4$

$5 \quad-16.7 \pm 0.3 \quad 13.3 \pm 0.6$

$5 \quad-17.3 \pm 0.3 \quad 12.8 \pm 0.1$

$5 \quad-17.5 \pm 0.1 \quad 12.7 \pm 0.3$ $\begin{array}{lll}10 & -18.6 \pm 0.3 & 11.2 \pm 0.7 \\ 45 & -17.7 \pm 0.3 & 12.4 \pm 0.7\end{array}$
12. Mackerel
13. Horse mackerel 
14. Anchovy

15. Sardine

16. Sprat

Engraulis encrasicolus

Sardina pilchardus

Sprattus sprattus

17. Benthic cephalopods

\section{Octopus vulgaris}

Rossia macrosoma

Sepia elegans

Sepia officinalis

Sepia orbignyana

Eledone cirrhosa

18. Pelagic cephalopods

Allotheutis spp.

Illex coindetii

Loligo forbesii

Loligo vulgaris

Todarodes sagittatus

Todaropsis eblanae
100

$-18.2 \pm 0.7$

$-18.0 \pm 0.5$

$10.7 \pm 1.5$

100

32

$-17.8 \pm 0.3$

$11.2 \pm 0.7$

$12.2 \pm 0.5$

10.31

$-16.9 \pm 0.4$

$-16.9 \pm 0.6$

$-17.3 \pm 0.3$

$12.0 \pm 0.8$

0.43

22.14

39.12

6.48

21.51

$-17.2 \pm 0.3$

$-16.7 \pm 0.5$

$-17.5 \pm 0.3$

$-16.8 \pm 0.5$

$11.1 \pm 0.4$

$10.6 \pm 0.6$

$11.7 \pm 0.6$

$12.7 \pm 1.2$

$10.8 \pm 0.7$

$11.7 \pm 0.6$

13.46

16.35

19.60

46.67

0.40

3.52
$-17.3 \pm 0.5 \quad 13.0 \pm 0.9$

$-17.7 \pm 0.2 \quad 12.3 \pm 0.3$

$-18.2 \pm 0.3 \quad 11.6 \pm 0.6$

$-17.5 \pm 0.7 \quad 13.0 \pm 1.0$

$-16.6 \pm 0.6 \quad 13.9 \pm 1.3$

$-17.9 \pm 0.4 \quad 11.9 \pm 0.7$

$-18.1 \pm 0.4 \quad 12.3 \pm 0.9$


Supplementary Table 3: values of some trophic enrichment factors (TEFs) available in the literature for different consumers (i.e. from different taxa), and

TEFs finally used to calculate trophic level (TL) of organisms in this study from stable isotope ratios.

\begin{tabular}{|c|c|c|c|}
\hline Taxa & TEF from the literature (examples) & Reference & TEF finally used in TL calculation and explanation \\
\hline $\begin{array}{l}\text { Actinopterygian } \\
\text { fish }\end{array}$ & Wide range of values in various species & $\begin{array}{l}\text { Vanderklift and Ponsard (2003) } \\
\text { Sweeting et al. (2007), Caut et al. (2009) }\end{array}$ & $\begin{array}{l}3.2 \text { (as recommended by Sweeting et al. (2007), the } \\
\text { most specific study for } \delta^{15} \mathrm{~N} \text { TEF in Actinopterygian } \\
\text { fish muscle) }\end{array}$ \\
\hline $\begin{array}{l}\text { Chondrichthyan } \\
\text { fish }\end{array}$ & $\begin{array}{l}2.3 \text { in average in sand tiger (Carcharias taurus, } \\
n=3 \text { ) and lemon shark (Negaprion brevirostris, } \\
n=1 \text { ) }\end{array}$ & $\begin{array}{l}\text { Hussey et al. (2010a) (see also Hussey } \\
\text { et al. (2010b), Logan and Lutcavage } \\
(2010))\end{array}$ & $\begin{array}{l}2.3 \text { (as recommended by Hussey et al. ( } 2010 a \text { ), the most } \\
\text { specific study of } \delta^{15} \mathrm{~N} \text { TEF in Chondrichthyan fish } \\
\text { muscle) }\end{array}$ \\
\hline Crustaceans & $\begin{array}{l}3.3 \text { in red rock lobster (Jasus edwardsii, } \mathrm{n}=69 \text { ) } \\
3.6 \text { to } 3.7 \text { in ghost shrimps (Nihonotrypaea } \\
\text { japonica, } \mathrm{n}=14 \text { and } N \text {. harmandii, } \mathrm{n}=13 \text { ) }\end{array}$ & $\begin{array}{l}\text { Suring and Wing (2009) } \\
\text { Yokoyama et al. (2005) }\end{array}$ & $\begin{array}{l}3.4 \text { for all invertebrates (as recommended by Post (2002) } \\
\text { in general, and due to the general lack of specific data) }\end{array}$ \\
\hline $\begin{array}{l}\text { Cephalopods } \\
\text { molluscs }\end{array}$ & 3.3 in common cuttlefish (Sepia officinalis, $n=5$ ) & Hobson and Cherel (2006) & \\
\hline
\end{tabular}


Caut, S., Angulo, E., Courchamp, F., 2009. Variation in discrimination factors $\left(\Delta^{15} \mathrm{~N}\right.$ and $\left.\Delta^{13} \mathrm{C}\right)$ : the effect of diet isotopic values and applications for diet reconstruction. Journal of Applied Ecology 46, 443-453.

Hobson, K.A., Cherel, Y., 2006. Isotopic reconstruction of marine food webs using cephalopod beaks: new insight from captively raised Sepia officinalis. Canadian Journal of Zoology 84, 766-770.

Hussey, N.E., Brush, J., McCarthy, I.D., Fisk, A.T., 2010a. $\delta^{15} \mathrm{~N}$ and $\delta^{13} \mathrm{C}$ diet-tissue discrimination factors for large sharks under semi-controlled conditions. Comparative Biochemistry and Physiology Part A: Molecular \& Integrative Physiology $155,445-453$.

Hussey, N.E., MacNeil, M.A., Fisk, A.T., 2010b. The requirement for accurate diet-tissue discrimination factors for interpreting stable isotopes in sharks. Hydrobiologia 654, 1-5.

Logan, J.M., Lutcavage, M.E., 2010. Stable isotope dynamics in elasmobranch fishes. Hydrobiologia 644, 231-244.

Post, D.M., 2002. Using stable isotopes to estimate trophic position: models, methods and assumptions. Ecology 83, 703-718.

Suring, E., Wing, S.R., 2009. Isotopic turnover rate and fractionation in multiple tissues of red rock lobster (Jasus edwardsii) and blue cod (Parapercis colias): consequences for ecological studies. Journal of Experimental Marine Biology and Ecology 370, 56-63.

Sweeting, C.J., Barry, J., Barnes, C., Polunin, N.V.C., Jennings, S., 2007. Effects of body size and environment on diettissue $\delta^{15} \mathrm{~N}$ fractionation in fishes. Journal of Experimental Marine Biology and Ecology 340, 1-10.

Vanderklift, M.A., Ponsard, S., 2003. Sources of variation in consumer-diet $\delta^{15} \mathrm{~N}$ enrichment: a meta-analysis. Oecologia $136,169-182$.

Yokoyama, H., Tamaki, A., Harada, K., Shimoda, K., Koyama, K., Ishihi, Y., 2005. Variability of diet-tissue isotopic fractionation in estuarine macrobenthos. Marine Ecology Progress Series 296, 115-128. 